\title{
Comparative Analysis on the Flow-Performance Relationship between Public Equity and Fiduciary Pension Funds
}

\author{
Mun-Kyung Cheong, Adjunct Professor, Hongik University \\ Hyun-Mo Sung ${ }^{*}$, Associate Professor, Handong Global University \\ Jay Kang, Student, Handong Global University
}

\begin{abstract}
$\langle$ Abstract〉
This study analyzes the flow-performance relationship and the convexity of public equity and fiduciary pension funds in Korea from January 2003 to May 2016. The empirical impli-cations are as follows: First, as shown in the literature, a statistically significant positive correlation exists between cash flows and the performance of public equity and fiduciary pension funds. Second, flow-performance convexity is found for public equity funds but not for fiduciary pension funds. This may be due to the difference in investor characteristics be-tween the public equity and fiduciary pension funds, rather than the difference in investor taxability, as, unlike in the US, Korean public equity fund investors are exempt from capital gain taxes.
\end{abstract}

Keywords: Public Equity Funds; Fiduciary Pension Funds; Performance; Flow; Convexity JEL Classification: G10, G20

* Corresponding Author. Address: School of Management and Economics, Handong Global University, 558 Handong-ro, Heunghae, Buk-gu, Pohang, Gyeongbuk, Korea 37554;

E-mail: hmsung@handong.edu; Tel: +82-54-260-1439; Fax: +82-54-260-1419.

Received: February 20, 2019; Revised: May 11, 2019; Accepted: May 20, 2019 


\title{
공모펀드와 연기금 위탁펀드의 성과와 현금흐름 관계에 관한 비교 연구
}

\author{
정 문 경 (홍익대학교 겸임교수) \\ 성 현 모 (한동대학교 부교수)* \\ 강 장 원 (한동대학교 학생)
}

\begin{abstract}
본 연구의 목적은 국내주식 공모펀드와 연기금 국내주식 위탁운용펀드의 성과와 현금흐름의 관계에 대해 비교 분석하여 연기금 위탁운용펀드가 과연 공모펀드와 같은 과거 성과와 현금흐름 간의 비대칭적인 볼록성의 관계를 나타내고 있는지를 검증하는 것이다. 2003년 1월 초부터 2016년 5월 말까지 국내주식 공모펀드와 연기금 위탁펀드를 대상으로 하여 실증적으로 현금흐름과 운용성과와의 관계를 비교 분석한 결과는 다음과 같다. 첫째, 기존 연구들의 결과와 비슷하게 공모펀드와 연기금 위탁펀드에 공통적으로 현금흐름과 전기의 성과와는 통계적으로 유의한 양의 상관관계가 있다. 둘째, 공모펀드의 경우 기존 연구 결과와 같이 전기 성과와 현금흐름 간에는 볼록성의 관계가 있지만 연기금 위탁펀드의 경우에는 볼록성의 관계가 없는 것으로 나타났다. 이와 같이 공모펀드와 연기금 위탁펀드에 대해 다른 결과가 나타난 것에 대해 본 연구의 결과는 중요한 의미를 갖는다. 미국과는 달리 주식형 펀드의 매매차익으로 인한 자본이득에 대해서 소득세가 비과세되는 한국의 경우에도 미국의 경우와 동일한 결과를 얻었다는 것은 공모펀드와 연기금 위탁펀드 투자자들에 대해 과세대상 여부의 차이점 때문에 다른 결과가 나타난 것이라는 설명보다는 공모펀드와 연기금 위탁펀드 투자자들의 특성의 차이점 때문에 다른 결과가 나타난다는 설명을 지지하는 결과인 것이다.
\end{abstract}

핵심 단어: 공모펀드, 연기금 위탁펀드, 성과, 현금흐름, 볼록성

JEL 분류기호: G10, G20

* 연락담당 저자. 주소: 경북 포항시 북구 흥해읍 한동로 558 한동대학교 경영경제학부, 37554; E-mail: hmsung@handong.edu; Tel: 054-260-1439; Fax: 054-260-1419. 


\section{1. 서론}

펀드의 현금흐름이 어떤 요인에 의해서 결정되느냐 하는 질문에 대한 답을 구하기 위해 지금까지 많은 연구들이 행해져 왔고 많은 연구들이 펀드의 현금흐름을 결정하는 많은 요인들 가운데 가장 중요한 요인 중에 하나가 과거의 펀드 성과이며 이 펀드의 과거 성과와 현금흐름 간에는 비대칭적인 볼록성의 관계가 있음을 보고하였다(Chevalier and Ellison, 1997; Sirri and Tufano, 1998; Del Guercio and Tkac, 2002; Ferreira et al., 2012; Spiegel and Zhang, 2013; Ha et al., 2014; Paek and Ko, 2016). 펀드의 과거 성과와 현금흐름 간에 비대칭적인 볼록성의 관계가 있다는 것은, 첫째는 성과가 좋은 펀드에는 현금흐름의 유입이 많다는 것이고, 둘째는 성과가 저조한 펀드임에도 불구하고 현금유출이 그리 많지 않다는 것을 의미한다.

이와 같은 현상에 대해 공모펀드의 투자자들은 자본 이득에 대해 과세 대상이어서 성과가 저조한 펀드를 환매할 때 자본 이득이 있을 경우 그에 대한 세금을 내야하는 부담이 있고, 공모펀드의 투자자들은 다수가 은퇴 후의 노후 자금을 저축하기 위해 펀드에 투자한 경우로서 장기간 투자를 하고 자동 이체 등을 통해 주기적으로 투자하며 단기적인 성과에 크게 영향을 받지 않는 특성을 가지고 있기 때문에 발생하는 현상이라고 이해되어 왔다.

이와 같은 기존 연구들은 대부분 공모펀드의 과거 성과와 현금흐름 간의 관계에 대한 것이고 공모펀드와는 성격이 다른 연기금 위탁펀드의 과거 성과와 현금흐름 간의 관계에 대한 연구는 그리 많지 않다. 공모펀드와 연기금 위탁펀드의 성과와 현금흐름과의 관계를 검증한 국외 연구로는 미국의 연 자료를 사용하여 공모펀드와 연기금 펀드의 전기 성과와 현금흐름의 관계를 분석한 Del Guercio and Tkac(2002)의 연구가 있으나, 국내 연구는 대부분 공모펀드에 대한 연구이고 연기금 위탁펀드에 대한 연구는 거의 없어 연기금의 국내주식 위탁펀드의 성과와 현금흐름과의 관계가 어떠한지는 지금까지 알려진 바가 없다. Del Guercio and Tkac (2002)의 연구에 의하면 연기금 펀드의 성과와 현금흐름과의 관계는 공모펀드의 그것과는 많은 차이가 있고 공모펀드에서 관찰되었던 펀드의 과거 성과와 현금흐름 간에는 비대칭적인 볼록성의 관계가 없다고 보고하였다.

따라서 본 연구는 국내주식 공모펀드와 연기금의 국내주식 위탁운용펀드의 성과와 현금흐름의 관계에 대해 비교 분석하여 연기금 위탁펀드가 과연 공모펀드와 같은 과거 성과와 현금흐름 간의 비대칭적인 볼록성의 관계를 나타내고 있는지 아니면 Del Guercio and Tkac(2002)의 연구 결과와 동일하게 공모펀드와는 다른 결과를 보이는지를 검증하여 공모펀드와 연기금펀드 운용에 대한 시사점을 도출하는데 주된 목적이 있다.

2003년 1월 초부터 2016년 5월 말까지 국내주식 공모펀드와 연기금 위탁펀드를 대상으로 하여 실증적으로 현금흐름과 운용성과와의 관계를 비교 분석한 결과는 다음과 같다. 첫째, OLS 회귀분석을 통해 일반적인 과거 성과와 현금흐름과의 관계를 먼저 살펴본 결과 기존 연구들의 결과와 비슷하게 공모펀드와 연기금 위탁펀드에 공통적으로 현금흐름과 전기의 성과와는 통계 적으로 유의한 양의 상관관계가 있다. 둘째, 공모펀드와 연기금 위탁펀드의 성과와 현금흐름의 볼록성 관계의 존재 여부를 확인하기 위해 단계적 선형 회귀분석(piecewise regression) 모형을 
추정하여 과거 성과와 현금흐름의 관계를 검증한 결과 공모펀드의 경우 기존 연구 결과와 같이 전기 성과와 현금흐름 간에는 볼록성의 관계가 있지만 연기금 위탁펀드의 경우에는 볼록성의 관계가 없는 것으로 나타났다. 이는 미국의 연 자료를 사용하여 연기금펀드에 대해서 전기 성과와 현금흐름 간에는 볼록성의 관계가 없는 것을 보인 Del Guercio and Tkac(2002)의 결과와 비슷한 결과이다.

이와 같이 공모펀드와 연기금 위탁펀드에 대해 다른 결과가 나타난 것에 대한 설명은 두 가지로 요약할 수 있는데 첫 번째는 공모펀드와 연기금 위탁펀드 투자자들에 대해 과세대상 여부의 차이점 때문에 이와 같은 현상이 발생할 수 있다는 것이고, 두 번째는 공모펀드와 연기금 위탁펀드 투자자들의 특성의 차이점 때문에 이와 같은 현상이 발생할 수 있다는 것이다. 이에 대해 본 연구의 결과는 다음과 같은 중요한 의미를 가진다. 즉, 미국과는 달리 주식형 펀드에 대해서는 매매차익으로 인한 자본이득에 대해서 소득세가 비과세되는 한국의 경우에도 미국의 경우와 동일한 결과를 얻었다는 것은 공모펀드와 연기금 위탁펀드 투자자들에 대해 과세대상 여부의 차이점 때문에 이와 같은 현상이 발생할 수 있다고 한 첫 번째 설명은 큰 설명력이 없고 두 번째 설명이 더 설득력이 있다는 증거를 제시하고 있다.

본 연구는 기존 연구에 더하여 다음과 같은 학문적 기여가 있다고 판단된다. 첫째, 공모펀드의 성과와 현금흐름과의 관계를 검증한 국내 연구는 다수 있지만 국내 연기금 위탁펀드에 대한 연구는 거의 없어 국내 연기금 위탁펀드의 성과와 현금흐름과의 관계를 실증 분석한 본 연구가 국내 펀드 연구에 기여하는 바가 있다. 둘째, 기존 연구들은 사용한 자료나 성과를 측정하기 위해 사용한 지표가 서로 다른 경우가 많아서 서로 비교하는데 어려움이 있고 결과의 확실성에 대해서도 의문의 여지가 있었다. 예를 들면, Del Guercio and Tkac(2002)은 연 자료를 사용하였고 Spiegel and Zhang(2013)은 월 자료를 사용하였다. 또한 펀드의 성과 지표로 Del Guercio and Tkac(2002)은 벤치마크 대비 초과수익률과 Jensen 알파를 사용하였고 Paek and $\mathrm{Ko}$ (2016)는 비용 차감 후 펀드 수익률을 사용하였다. 본 연구는 이러한 문제점을 해결하기 위해 월 자료뿐만 아니라 6개월, 연 자료를 사용하였고 성과지표도 벤치마크 대비 초과수익률 뿐만 아니라 다른 위험조정지표인 Jensen 알파, Fama-French 알파, 그리고 Carhart 알파를 사용하여 강건성 검증을 하였으므로 좀 더 신뢰할 수 있는 결과를 도출하였다. 셋째, 미국의 자료를 사용하여 연기금펀드에 대해서 전기 성과와 현금흐름 간에는 볼록성의 관계가 없는 것을 보인 Del Guercio and Tkac(2002)의 연구결과와 본 연구의 결과가 동일하다는 것을 보임으로써 공모펀드와 연기금 위탁펀드에 대해 다른 결과가 나타난 것은 공모펀드와 연기금 위탁펀드 투자자들의 과세대상 여부의 차이가 아니라 투자자들의 특성의 차이점 때문이라는 점을 밝힌 것이다.

본 연구의 내용은 다음과 같다. 먼저 제 2장에서는 국내주식 공모펀드와 연기금 위탁펀드의 성과와 현금흐름의 관계 분석에 사용된 자료와 방법론을 설명하였다. 제 3장에서는 국내주식 공모펀드와 연기금 위탁펀드를 대상으로 성과와 현금흐름의 관계를 비교 분석하였다. 마지막으로 제 4 장에서는 국내주식 공모펀드와 연기금 위탁펀드의 성과와 현금흐름 관계의 비교 분석 결과에 대한 결론을 서술하였다. 


\section{2. 자료와 방법론}

\section{1 자료}

본 연구는 국내주식 공모펀드와 연기금 위탁펀드를 대상으로 하여 실증적으로 현금흐름과 운용성과와의 관계를 비교 분석하는 것이 목적이다. 분석 기간은 2003년 1월 초부터 2016년 5 월 말까지이고, 펀드의 비용차감 후 수익률은 월간 주간 단위로 측정하였다.1) 연기금 위탁펀드 자료는 국내의 대표적인 한 연기금 공단으로부터 자료를 제공 받았으며, 국내주식 공모펀드의 자료는 제로인으로부터 제공받았다. 실증분석 대상인 공모펀드의 총 샘플 펀드 수는 5,003 개이며 연기금 위탁펀드는 총 166 개이다. <표 1 >은 분석에 사용된 공모 주식펀드와 연기금 국내주식 위탁펀드의 분석기간, 벤치마크지수 및 샘플 펀드 수를 나타낸 표이다(Cheong el al., 2015).

\section{〈표 1〉 분석 대상 펀드}

이 표는 분석에 사용된 공모 주식펀드와 연기금 위탁펀드의 분석기간, 벤치마크지수 및 샘플 펀드 수를 나타낸 표이다.

\begin{tabular}{lll}
\hline & \multicolumn{1}{c}{ 공모 주식펀드 } & 연기금 국내주식 위탁펀드 \\
\hline 분석기간 & 2003년 1월 2016년 5월 & \\
벤치마크 & KOSPI, KOSPI200 총수익지수1) & KOSPI, KOSPI200, KOSPI\& \\
& & KOSDAQ100 총수익지수 \\
샘플 펀드 수 & 5,003 & 166 \\
\hline
\end{tabular}

주) 1) 공모펀드 중에서 본 연구의 대상이 되는 액티브 펀드들은 대부분 KOSPI 또는 KOSPI200을 벤치마크로 지정하고 있는데, 본 연구에서는 KOSPI 또는 KOSPI200이 아닌 다른 벤치마크를 사용하는 일부 펀드의 경우 $\mathrm{KOSPI}$ 를 벤치마크로 하였다.

\section{2 성과평가지표}

국내주식 공모펀드와 연기금 위탁펀드의 성과 측정은 연기금 위탁펀드에 대한 평가지표인 벤치마크 대비 초과수익률과 주식형펀드에 대한 대표적인 위험조정 초과성과지표를 기준으로 실시하였다.

국내주식 공모펀드의 벤치마크는 KOSPI를 사용하였고, 연기금 국내주식 위탁펀드의 벤치마크는 유형별 벤치마크가 사용되었다. 따라서 벤치마크 대비 초과수익률은 실제 수익률과 벤치마크 수익률(배당포함)의 차이이다.

위험조정 초과성과지표로는 Jensen 알파, Fama-French 알파, 그리고 Carhart 알파를 사용하였다. 알파추정은 과거 1년간 주간 수익률을 이용하여 베타를 추정한 후 이를 기준으로 당해 월의 펀드수익률에서 위험조정수익률을 차감하여 알파를 추정하였다. 예를 들면 2008년도 1월의 Jensen(1968) 알파를 추정하기 위해서 2007년도 1월부터 2007년도 12월까지의 주간 수익률을 이용하여 시장베타를 추정한 후 2008년도 1월의 펀드의 Jensen 알파를 추정하였다.

1) 연기금 위탁펀드와 공모펀드와의 비교를 위하여 두 펀드 그룹에 대해 동일한 분석 기간을 적용하였다. 그러나 동 기간 중 금융위기가 발생한 기간이 있어서 실증분석 결과가 제한적일 수 있다. 
본 연구에서 Fama-French의 3요인 수익률 산출을 위해 에프앤가이드로부터 주식수익률 자료를 제공받았다. Fama-French의 방법에 따라 3요인을 구성한 방법은 다음과 같다. 우선, 유가증권시장과 코스닥시장에 상장된 주식을 대상으로 그 해 6월 말 시가총액에 따라 50/50\%로 정렬하였다. 다음으로 각 시장규모그룹에 속한 주식에 대하여 지난 회계연도 순자산 장부가치2) 대 지난해 12 월말의 시장가치의 비율에 따라 $30 / 40 / 30 \%$ 의 세 그룹을 생성하였다. 이와 같은 과정에 의해 생성된 총 6 개의 포트폴리오를 1 년 간 보유하면서 각 포트폴리오에 대하여 가중평균 수익률을 계산하였다. SMB(small minus big) 포트폴리오 수익률은 6개 포트폴리오 수익률 자료를 바탕으로 회사규모가 작은 3개와 큰 3개의 포트폴리오의 평균 수익률 차이로, HML(high minus low) 포트폴리오 수익률은 장부 대 시장가치가 작은 2 개와 큰 2 개 포트폴리오의 평균수익률 차이로 산출되었다. 시장수익률은 배당을 포함한 유가증권시장과 코스닥시장에 상장된 보통주의 가중평균수익률로 정의하였고, 무위험이자율은 통안증권 만기 3개월의 수익률로 정의하였다.

Carhart(1997)는 Fama and French(1993)의 3요인에 모멘텀 요인을 추가한 4요인 모형을 이용하여 펀드의 성과를 측정하였다. 본 연구에서 추정한 모멘텀 요인의 수익률은 Carhart의 방법론에 따라 계산되었는데, $\mathrm{t}-12$ 월부터 $\mathrm{t}-2$ 월 말 시점까지의 과거 11 개월 동안의 수정주가 수익률을 기준으로 30/40/30\%의 세 그룹을 생성하였다. 각 그룹에 대한 t월 한 달 동안 보유하면서 각 포트폴리오의 동일 가중 수익률을 계산하였다. 따라서 $\mathrm{t}$ 월의 모멘텀 요인의 수익률은 과거 성과가 높은 상위 $30 \%$ 포트폴리오의 평균 수익률과 과거 성과가 낮은 하위 $30 \%$ 포트폴리오의 평균 수익률의 차이이다.

모든 성과평가지표는 기본적으로 월별로 작성하였고 기간에 따라 결과가 어떻게 달라지는지 알아보기 위해 월별 자료를 6 개월과 1 년 자료로 변환하여 얻은 결과도 함께 제시하였다.

\section{3 현금흐름}

국내주식 공모펀드와 연기금 국내주식 위탁펀드의 현금흐름은 펀드의 월별 순자산총액과 월별 수익률을 사용하여 다음과 같이 추정하였다.

$$
F \operatorname{Fow}_{i, t}=\frac{T N A_{i, t}-T N A_{i, t-1}\left(1+r_{i, t}\right)}{T N A_{i, t-1}}
$$

여기서 $F$ Fow $_{i, t}$ 는 펀드 $i$ 의 $t$ 월 현금흐름, $T N A_{i, t}$ 는 펀드 $i$ 의 $t$ 월 말 순자산총액, $r_{i, t}$ 는 펀드 $i$ 의 $t$ 월 수익률이다. 동일한 방법으로 6 개월과 1 년의 현금흐름도 추정하였다. 극단적인 현금흐름 값으로 인한 추정 오류를 줄이기 위하여 현금흐름 분포에서 상위 $1 \%$ 와 하위 $1 \%$ 의 값들은 기존 연구에서 많이 사용하였던 winsorize 방법을(Ferreira et al., 2012) 적용하여 분석에서 사용하였다.

2) 순자산은 전년도 12 월 말 기준의 자본총계-무형자산+자기주식으로 산출되고, 시가총액은 전년도 12 월 말 기준의 보통주 시가총액+우선주 시가총액으로 산출됨. 


\section{4 기타 통제변수}

기존 연구를 바탕으로 동일한 펀드의 과거 현금흐름, 연령, 규모, 펀드 수익률의 표준편차, 자산운용사의 규모를 통제 변수로 사용하였고, 연도별 효과를 통제하기 위해 연도 더미를 포함 하였다(Chevalier and Ellison, 1997; Sirri and Tufano, 1998; Spiegel and Zhang, 2013; Paek and Ko, 2016).3) 또한 Kacperczyk et al.(2005)은 우수한 운용능력을 지닌 펀드매니저는 특정 산업에 집중된 포트폴리오를 구성함으로써 자신의 높은 성과를 실현할 수 있음을 보였다. 따라서 본 연구에서는 펀드의 각 산업별 투자 비중과 전체 시장의 산업별 구성 비중의 차이의 제곱을 더한 지수인 산업집중도(Industry Concentration Index)를 통제 변수로 사용하였다. 끝으로 Del Guercio and Tkac(2002)는 공모펀드의 현금흐름과 트레킹에러와는 관계가 없지만 성과가 좋은 연기금 위탁펀드의 현금흐름과 트레킹에러와는 유의한 음의 관계가 있음을 보고 하였다. 따라서 본 연구에서도 트레킹에러를 통제 변수로 사용하였다.

\section{3. 실증분석 결과}

\section{1 기초 통계량}

<표 2>에는 본 분석에 포함된 공모 주식펀드와 연기금 위탁주식펀드에 대한 변수들의 기초 통계량이 제시되어 있다. Panel A, Panel B, Panel C는 각각 월별 자료, 6개월 자료, 연 자료를 이용하여 펀드의 현금흐름(Flow), 벤치마크 대비 초과수익률(BM 초과), Jensen 알파, FamaFrench 알파(F-F알파), Carhart 알파, 펀드의 자산운용사가 운용하는 전체 펀드들의 순자산 총액(Familysize, 십억 원), 펀드의 과거 12 개월간 주간수익률의 표준편차(Annualvol), 펀드의 산업집중도(ICI), 펀드의 트레킹에러(TE), 펀드연령(Fundage, 월), 펀드의 순자산(Assetsize, 십억 원)의 통계량을 제시하고 있다.

현금흐름의 경우 공모펀드는 월별 자료, 6 개월 자료, 연 자료에서 평균이 각각 $0.04,0.179$, 0.286 이고, 연기금 위탁펀드는 각각 $0.195,0.129,0.368$ 이다. 한 가지 특이한 점은 공모펀드의 경우 양과 음의 현금흐름이 모두 관찰되지만 연기금 위탁펀드의 경우는 주로 양의 현금흐름이 관찰된다는 점이다. 이는 공모펀드와 연기금 위탁펀드의 성과평가에 따른 투자자들의 반응의 차이에 기인하는 것으로 추정된다. 공모펀드의 경우 성과에 따라 투자자들이 즉시 추가 투자나 감액, 회수 등을 결정하고 실행하지만 연기금 위탁펀드의 경우 일반적으로 정기평가를 바탕으로 사후관리를 하므로 공모펀드와는 다른 현금흐름의 분포가 발생하는 것으로 보인다.

3) 일부 기존 연구(Sirri and Tufano, 1998; Ferreira et al., 2012; Spiegel and Zhang, 2013; Paek and Ko, 2016)에서는 펀드 비용을 통제 변수로 사용하였으나 본 연구에서는 연기금 위탁펀드의 비용 자료를 구하는데 제한이 있어 통제 변수로 사용하지 못하였다. 그러나 Ferreira et al.(2012)의 결과를 보면 펀드 비용과 현금흐름 사이에 통계적으로 유의한 관계가 없는 것으로 나타났고 펀드 비용을 통제 변수로 사용할 때와 사용하지 않을 때의 회귀분석 결과가 차이가 없는 것으로 나타나 본 연구에서 펀드 비용을 통제 변수에 포함시키지 않은 것이 연구 결과에 큰 영향을 미치지 않을 것으로 판단된다. 
Comparative Analysis on the Flow-Performance Relationship between Public Equity and Fiduciary Pension Funds

성과평가지표 중 $\mathrm{BM}$ 초과의 경우 공모펀드는 월별 자료, 6 개월 자료, 연 자료에서 평균이 각각 $0.001,0.012,0.025$ 이고, 연기금 위탁펀드는 각각 $0.002,0.015,0.036$ 으로 일반적으로 연기금 위탁펀드가 공모펀드에 비해 높은 BM 대비 초과수익률을 보이고 있다. Jensen 알파, FamaFrench 알파, Carhart 알파의 경우에도 일반적으로 연기금 위탁펀드가 공모펀드에 비해 높은 성과를 보이고 있다.

펀드의 자산운용사가 운용하는 전체 펀드들의 순자산 총액(Familysize, 십억 원)의 경우 공모펀드는 연 자료에서 평균이 7,510(십억 원)이고, 연기금 위탁펀드는 6,340 (십억 원)으로 나타나 일반적으로 공모펀드가 연기금 위탁펀드에 비해 크다.

펀드의 과거 12 개월간 주간수익률의 표준편차(Annualvol)의 경우 공모펀드와 연기금 위탁 펀드는 비슷한 행태를 보이고 있고, 펀드의 산업집중도(ICI)와 펀드의 트레킹에러(TE)는 공모펀드가 연기금 위탁펀드에 비해 높은 수치를 보이고 있다. 펀드연령(Fundage, 월)의 경우 공모펀드는 연 자료에서 평균이 각각 63 개월이고, 연기금 위탁펀드는 56 개월로 일반적으로 공모펀드가 연기금 위탁펀드에 비해 펀드연령이 높은 것으로 나타났다. 끝으로, 펀드의 순자산 (Assetsize, 십억 원)의 경우 공모펀드는 연 자료에서 평균이 683억 원이고, 연기금 위탁펀드는 4,330 억 원으로 나타나 예상한 바와 같이 연기금 위탁펀드가 공모펀드에 비해 펀드크기가 월등히 큰 것으로 나타났다.

\section{〈표 2〉샘플 펀드의 기초 통계량}

Flow는 펀드의 현금흐름이고, BM 초과는 벤치마크 대비 초과수익률이며 F-F 알파는 Fama-French 알파다. Familysize는 펀드의 자산운용사가 운용하는 전체 펀드들의 순자산 총액(십억 원)이며, Annualvol는 펀드의 과거 12 개월간 주간수익률의 표준편차, ICI는 펀드의 산업집중도이고, $\mathrm{TE}$ 는 펀드의 트레킹에러이다. Fundage는 펀드연령(월)이고, Assetsize는 펀드의 순자산(십억 원)이다.

패널 $\mathrm{A}$ : 월별 현금흐름과 수익률

\begin{tabular}{|c|c|c|c|c|c|c|c|c|c|c|}
\hline \multirow[b]{2}{*}{ 설명변수 } & \multicolumn{5}{|c|}{ 공모 주식펀드 } & \multicolumn{5}{|c|}{ 연기금 위탁주식펀드 } \\
\hline & $25 \%$ & $50 \%$ & $75 \%$ & 평균 & $\begin{array}{l}\text { 표준 } \\
\text { 편차 }\end{array}$ & $25 \%$ & $50 \%$ & $75 \%$ & 평균 & $\begin{array}{l}\text { 표준 } \\
\text { 편차 }\end{array}$ \\
\hline Flow & -0.037 & -0.000 & 0.023 & 0.040 & 0.353 & $=0000$ & 0.000 & & 35 & 0.124 \\
\hline BM & -0.01 & 0.000 & & & & -0.0 & & & & 015 \\
\hline Jense & 0.00 & 0.003 & 0.0 & 0.0 & & & 0.0 & & & .003 \\
\hline F-F 알파 & 0.00 & 0.003 & 0.00 & 0.00 & & 0.00 & 0.00 & 0.0 & 0.06 & 0.003 \\
\hline Carhart 알파 & 0.000 & 0.003 & 0.00 & 0.00 & 0.0 & 0.002 & 0.004 & 0.00 & 0.004 & 0.003 \\
\hline Familysize & 1,850 & 5,110 & 11,200 & 7,050 & 6,250 & 1,440 & 4,000 & 8,930 & 5,940 & 5,790 \\
\hline Annualvol & 0.134 & 0.165 & 0.219 & 0.186 & 0.08 & 0.137 & 0.171 & 0.229 & 0.192 & 0.079 \\
\hline ICI & 0.011 & 0.019 & 0.043 & 0.071 & 0.18 & 0.011 & 0.016 & 0.028 & 0.030 & 0.081 \\
\hline TE & 0.045 & 0.064 & 0.084 & 0.069 & 0.052 & 0.029 & 0.045 & 0.060 & 0.046 & 0.023 \\
\hline Fundag & 21 & 47 & 77 & 54 & 45 & 16 & 37 & 68 & 46 & 37 \\
\hline Assetsize & 0.3 & 2.56 & 16.6 & 49.5 & 207 & 75.1 & 191 & 491 & 370 & 451 \\
\hline Sample & & & 5,003 & & & & & 166 & & \\
\hline
\end{tabular}


한국증권학회지 제 48 권 5 호 (2019)

〈표 2〉샘플 펀드의 기초 통계량(계속)

패널 B: 6 개월 현금흐름과 수익률

\begin{tabular}{|c|c|c|c|c|c|c|c|c|c|c|}
\hline \multirow[b]{2}{*}{ 설명변수 } & \multicolumn{5}{|c|}{ 공모 주식펀드 } & \multicolumn{5}{|c|}{ 연기금 위탁주식펀드 } \\
\hline & $25 \%$ & $50 \%$ & $75 \%$ & 평균 & $\begin{array}{l}\text { 표준 } \\
\text { 편차 }\end{array}$ & $25 \%$ & $50 \%$ & $75 \%$ & 평균 & $\begin{array}{l}\text { 표준 } \\
\text { 편차 }\end{array}$ \\
\hline Flow & -0.313 & -0.095 & 0.052 & 0.179 & 1.732 & -0.000 & 0.001 & 0.138 & 0.129 & 0.489 \\
\hline $\mathrm{BM}$ 초과 & -0.022 & 0.003 & 0.030 & 0.012 & 0.968 & -0.008 & 0.011 & 0.034 & 0.015 & 0.043 \\
\hline Jensen 알파 & 0.006 & 0.019 & 0.033 & 0.021 & 0.024 & 0.020 & 0.030 & 0.042 & 0.032 & 0.019 \\
\hline F-F 알파 & 0.007 & 0.020 & 0.032 & 0.020 & 0.025 & 0.018 & 0.028 & 0.037 & 0.028 & 0.016 \\
\hline Carhar & 0.002 & 0.018 & 0.030 & 0.01 & 0.02 & 0.013 & 0.024 & 0.034 & 0.024 & 0.017 \\
\hline Familysize & 1,980 & 5,390 & 11,600 & 7,230 & 6,270 & 1,530 & 4,040 & 9,440 & 6,090 & 5,800 \\
\hline Annualvol & 0.133 & 0.169 & 0.215 & 0.185 & 0.078 & 0.136 & 0.174 & 0.225 & 0.191 & 0.076 \\
\hline ICI & 0.011 & 0.019 & 0.040 & 0.068 & 0.177 & 0.011 & 0.016 & 0.028 & 0.031 & 0.074 \\
\hline TE & 0.045 & 0.063 & 0.082 & 0.067 & 0.042 & 0.029 & 0.044 & 0.059 & 0.045 & 0.022 \\
\hline Fundage & 26 & 51 & 79 & 58 & 44 & 22 & 42 & 72 & 50 & 36 \\
\hline Assetsize & 0.5 & 3.48 & 21.8 & 59.2 & 228 & 92.7 & 220 & 539 & 399 & 461 \\
\hline Sample & & & 4,394 & & & & & 152 & & \\
\hline
\end{tabular}

패널 C: 연 현금흐름과 수익률

\begin{tabular}{|c|c|c|c|c|c|c|c|c|c|c|}
\hline \multirow[b]{2}{*}{ 설명변수 } & \multicolumn{5}{|c|}{ 공모 주식펀드 } & \multicolumn{5}{|c|}{ 연기금 위탁주식펀드 } \\
\hline & $25 \%$ & $50 \%$ & $75 \%$ & 평균 & $\begin{array}{l}\text { 표준 } \\
\text { 편차 }\end{array}$ & $25 \%$ & $50 \%$ & $75 \%$ & 평균 & $\begin{array}{l}\text { 표준 } \\
\text { 편차 }\end{array}$ \\
\hline Flow & -0.563 & -0.242 & 0.000 & 0.286 & 2.893 & -0.001 & 0.029 & 0.416 & 0.368 & 1.070 \\
\hline $\mathrm{BM}$ 초과 & -0.029 & 0.008 & 0.050 & 0.025 & 1.525 & -0.000 & 0.025 & 0.068 & 0.036 & 0.070 \\
\hline Jensen 알파 & 0.013 & 0.038 & 0.06 & 0.04 & 0.04 & 0.0 & 0.059 & 0.0 & 0.06 & 0.039 \\
\hline F-F 알파 & 0.013 & 0.039 & 0.064 & 0.04 & 0.04 & 0.036 & 0.057 & 0.076 & 0.056 & 0.031 \\
\hline Carhart 알파 & 0.004 & 0.036 & 0.060 & 0.034 & $0.04^{7}$ & 0.025 & 0.047 & 0.067 & 0.047 & 0.033 \\
\hline Familysize & 2,320 & 6,180 & 12,500 & 7,510 & 6,220 & 1,780 & 4,400 & 9,890 & 6,340 & 5,730 \\
\hline Annualvol & 0.132 & 0.176 & 0.202 & 0.185 & 0.074 & 0.131 & 0.178 & 0.207 & 0.188 & 0.070 \\
\hline ICI & 0.012 & 0.019 & 0.039 & 0.066 & 0.172 & 0.011 & 0.016 & 0.028 & 0.029 & 0.061 \\
\hline TE & 0.046 & 0.063 & 0.081 & 0.066 & 0.039 & 0.029 & 0.045 & 0.059 & 0.045 & 0.022 \\
\hline Fundage & 32 & 56 & 84 & 63 & 44 & 28 & 47 & 76 & 56 & 36 \\
\hline Assetsize & 0.7 & 4.34 & 27 & 68.3 & 251 & 112 & 257 & 587 & 433 & 464 \\
\hline Sample & & & 3,859 & & & & & 128 & & \\
\hline
\end{tabular}

\section{2 공모펀드와 연기금 위탁펀드의 성과와 현금흐름 관계 비교 분석: OLS 회귀분석}

본 연구는 단계적 선형 회귀분석(Piecewise Regression) 모형을 추정하여 과거 성과와 현금흐름의 관계를 검증하기 전에 먼저 OLS 회귀분석을 통해 일반적인 과거 성과와 현금흐름과의 관계를 먼저 살펴보고자 한다. 종속변수는 위에서 정의한 현금흐름이며, 독립변수로는 벤치마크 대비 초과수익률, Jensen 알파, Fama-French 알파, 그리고 Carhart 알파의 네 개의 성과평가지표 (Performance)를 사용하여 각각의 성과평가지표에 대해 OLS 회귀분석을 실시하였다. 또한 공통적으로 개별펀드의 현금흐름에 영향을 줄 수 있는 펀드 특성을 통제 변수로 사용하였다. 
Comparative Analysis on the Flow-Performance Relationship between Public Equity and Fiduciary Pension Funds

Flow $_{\mathrm{i}, \mathrm{t}}=\mathrm{a}^{+} \mathrm{b}_{1}$ Performance $_{\mathrm{i}, \mathrm{t}-1}+\mathrm{b}_{2} \mathrm{LFamilysize}_{\mathrm{i}, \mathrm{t}}+\mathrm{b}_{3}$ Annualvol $_{\mathrm{i}, \mathrm{t}}+\mathrm{b}_{4} \mathrm{ICI}_{\mathrm{i}, \mathrm{t}}+\mathrm{b}_{5}$ Flow $_{\mathrm{i}, \mathrm{t}-1}$

$$
+\mathrm{b}_{6} \mathrm{TE}_{\mathrm{i}, \mathrm{t}}+\mathrm{b}_{7} \mathrm{LFundage}_{\mathrm{i}, \mathrm{t}}+\mathrm{b}_{8} \mathrm{LAssetsize}_{\mathrm{i}, \mathrm{t}}+\mathrm{b}_{9} \text { Yeardummy }_{\mathrm{i}, \mathrm{t}}+\mathrm{e}_{\mathrm{i}, \mathrm{t}}
$$

Flow $_{\mathrm{i}, \mathrm{L}}$ 는 펀드 $\mathrm{i}$ 의 $\mathrm{t}$ 시점에서의 현금흐름이고, Performance $\mathrm{e}_{\mathrm{i}, \mathrm{t}-1}$ 는 펀드 $\mathrm{i}$ 의 $\mathrm{t}-1$ 의 수익률이다.

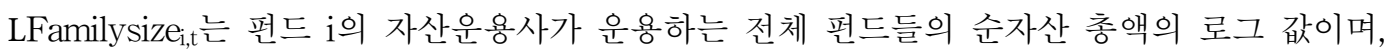
Annualvoli,t는 펀드 $i$ 의 과거 12 개월간 주간수익률의 표준편차, $\mathrm{ICI}_{\mathrm{i}, \mathrm{t}}$ 는 펀드 $\mathrm{i}$ 의 $\mathrm{t}$ 시점에서의 산업집중도이고, $\mathrm{Flow}_{\mathrm{i},-1}$ 는 펀드 $\mathrm{i}$ 의 전기 현금흐름, $\mathrm{TE}_{\mathrm{i}, \mathrm{L}}$ 펀드 $\mathrm{i}$ 의 $\mathrm{t}$ 시점에서의 트레킹에러이다. LFundage $\mathrm{i}_{i, \mathrm{~L}}$ 펀드 $\mathrm{i}$ 의 $\mathrm{t}$ 시점에서의 펀드연령(월)의 로그 값이고, LAssetsize $\mathrm{i}_{i, \mathrm{~L}}$ 펀드 $\mathrm{i}$ 의 t시점에서의 순자산의 로그 값이며, Yeardummyi,t는 연도 더미다.

$<$ 표 3>, <표 4>, <표 5>에는 각각 월별 자료, 6 개월 자료, 연 자료를 이용한 OLS 회귀분석 결과가 제시되어 있다. 모든 자료에 대해 공모펀드와 연기금 위탁펀드에 공통적으로 나타나는 결과는 현금흐름과 전기의 성과와는 통계적으로 유의한 양의 상관관계가 있고 현금흐름과 펀드의 크기와는 통계적으로 유의한 음의 상관관계가 있다는 것이다.

〈표 3〉월별 자료를 사용한 과거 성과와 현금흐름의 관계 분석

Flow $_{\mathrm{i}, \mathrm{t}}=\mathrm{a}^{+} \mathrm{b}_{1}$ Performance $_{\mathrm{i}, \mathrm{t}-1}+\mathrm{b}_{2} \mathrm{LFamilysize}_{\mathrm{i}, \mathrm{t}}+\mathrm{b}_{3}$ Annualvol $_{\mathrm{i}, \mathrm{t}}+\mathrm{b}_{4} \mathrm{ICI}_{\mathrm{i}, \mathrm{t}}+\mathrm{b}_{5} \mathrm{Flow}_{\mathrm{i}, \mathrm{t}-1}+\mathrm{b}_{6} \mathrm{TE}_{\mathrm{i}, \mathrm{t}}+\mathrm{b}_{7} \mathrm{LFundage}_{\mathrm{i}, \mathrm{t}}$ $+\mathrm{b}_{8} \mathrm{LAssetsize}_{\mathrm{i}, \mathrm{t}}+\mathrm{b}_{9}$ Yeardummy $\mathrm{i}_{\mathrm{i}, \mathrm{t}}+\mathrm{e}_{\mathrm{i}, \mathrm{t}}$ (OLS 회귀분석 모형)

Flow $_{\mathrm{i}, \mathrm{t}}$ 는 펀드 $\mathrm{i}$ 의 $\mathrm{t}$ 시점에서의 현금흐름이고, Performance $\mathrm{i}, \mathrm{t}-1$ 는 펀드 $\mathrm{i}$ 의 $\mathrm{t}-1$ 의 수익률이다. LFamilysize $\mathrm{e}_{\mathrm{i}, \mathrm{L}}$ 픈 펀드 $\mathrm{i}$ 의 자산운용사가 운용하는 전체 펀드들의 순자산 총액의 로그 값이며, Annualvolit는 펀드 $\mathrm{i}$ 의 과거 12 개월간 주간수익률의 표준편차, $\mathrm{IC}_{\mathrm{i}, \mathrm{t}}$ 는 펀드 $\mathrm{i}$ 의 $\mathrm{t}$ 시점에서의 산업집중도이고, $\mathrm{Flow}_{\mathrm{i}, \mathrm{t}-1}$ 는 펀드 $\mathrm{i}$ 의 전월 현금흐름, $\mathrm{TE}_{\mathrm{i}, \mathrm{t}}$ 는 펀드 $\mathrm{i}$ 의 $\mathrm{t}$ 시점에서의 트레킹에러이다. LFundage $\mathrm{i}_{\mathrm{t}, \mathrm{L}}$ 펀드 $\mathrm{i}$ 의 $\mathrm{t}$ 시점에서의 펀드연령의 로그 값이고, LAssetsize $\mathrm{i}, \mathrm{t}$ 는 펀드 $\mathrm{i}$ 의 $\mathrm{t}$ 시점에서의 순자산의 로그 값이며, Yeardummy $\mathrm{i}_{\mathrm{i}, \mathrm{L}}$ 연도 더미다. 괄호 안은 cluster robust 표준 오차이며 유의확률 $1 \%, 5 \%$, $10 \%$ 수준에 대하여 각각 ${ }^{* * *},{ }^{* *},{ }^{*}$ 로 표시하였다.

\begin{tabular}{|c|c|c|c|c|c|c|c|c|}
\hline \multirow[b]{2}{*}{ 설명변수 } & \multicolumn{4}{|c|}{ 공모 주식펀드 } & \multicolumn{4}{|c|}{ 연기금 위탁주식펀드 } \\
\hline & $\begin{array}{l}\mathrm{BM} \\
\text { 초과 }\end{array}$ & $\begin{array}{l}\text { Jensen } \\
\text { 알파 }\end{array}$ & $\begin{array}{l}\mathrm{F}-\mathrm{F} \\
\text { 알파 }\end{array}$ & $\begin{array}{c}\text { Carhart } \\
\text { 알파 }\end{array}$ & $\begin{array}{l}\mathrm{BM} \\
\text { 초과 }\end{array}$ & $\begin{array}{l}\text { Jensen } \\
\text { 알파 }\end{array}$ & $\begin{array}{l}\mathrm{F}-\mathrm{F} \\
\text { 알파 }\end{array}$ & $\begin{array}{c}\text { Carhart } \\
\text { 알파 }\end{array}$ \\
\hline Performance & $\begin{array}{c}0.530 \\
(0.028)^{* * * *}\end{array}$ & $\begin{array}{c}4.139 \\
(0.177)^{* * *}\end{array}$ & $\begin{array}{c}3.093 \\
(0.167)^{* * * *}\end{array}$ & $\begin{array}{c}2.780 \\
(0.165)^{* * * *}\end{array}$ & $\begin{array}{c}0.346 \\
(0.088)^{* * * *}\end{array}$ & $\begin{array}{c}2.691 \\
(0.509)^{* * * *}\end{array}$ & $\begin{array}{c}3.821 \\
(0.550)^{* * * *}\end{array}$ & $\begin{array}{c}3.876 \\
(0.564)^{* * * *}\end{array}$ \\
\hline LFamilysize & $\begin{array}{c}0.003 \\
(0.001)^{* * * *}\end{array}$ & $\begin{array}{l}-0.000 \\
(0.001)\end{array}$ & $\begin{array}{l}-0.000 \\
(0.001)\end{array}$ & $\begin{array}{r}0.000 \\
(0.001)\end{array}$ & $\begin{array}{c}0.003 \\
(0.001)^{*}\end{array}$ & $\begin{array}{r}0.001 \\
(0.002)\end{array}$ & $\begin{array}{r}0.001 \\
(0.002)\end{array}$ & $\begin{array}{r}0.001 \\
(0.002)\end{array}$ \\
\hline Annualvol & $\begin{array}{c}0.064 \\
(0.009)^{* * * *}\end{array}$ & $\begin{array}{c}0.104 \\
(0.011)^{* * * *}\end{array}$ & $\begin{array}{c}0.110 \\
(0.011)^{* * * *}\end{array}$ & $\begin{array}{c}0.108 \\
(0.011)^{* * * *}\end{array}$ & $\begin{array}{l}-0.061 \\
(0.020)^{* * *}\end{array}$ & $\begin{array}{l}-0.099 \\
(0.024)^{* * * *}\end{array}$ & $\begin{array}{l}-0.110 \\
(0.024)^{* * * *}\end{array}$ & $\begin{array}{l}-0.117 \\
(0.024)^{* * * *}\end{array}$ \\
\hline ICI & $\begin{array}{r}0.003 \\
(0.003)\end{array}$ & $\begin{array}{c}0.014 \\
(0.004)^{* * * *}\end{array}$ & $\begin{array}{c}0.009 \\
(0.004)^{* *}\end{array}$ & $\begin{array}{r}0.006 \\
(0.004)\end{array}$ & $\begin{array}{l}-0.055 \\
(0.016)^{* * *}\end{array}$ & $\begin{array}{l}-0.092 \\
(0.028)^{* * *}\end{array}$ & $\begin{array}{l}-0.083 \\
(0.028)^{* * *}\end{array}$ & $\begin{array}{l}-0.075 \\
(0.028)^{* * * *}\end{array}$ \\
\hline Flow $(t-1)$ & $\begin{array}{c}0.192 \\
(0.002)^{* * * *}\end{array}$ & $\begin{array}{c}0.226 \\
(0.003)^{* * *}\end{array}$ & $\begin{array}{c}0.227 \\
(0.003)^{* * *}\end{array}$ & $\begin{array}{c}0.228 \\
(0.003)^{* * *}\end{array}$ & $\begin{array}{c}0.136 \\
(0.012)^{* * *}\end{array}$ & $\begin{array}{c}0.169 \\
(0.016)^{* * *}\end{array}$ & $\begin{array}{c}0.164 \\
(0.016)^{* * *}\end{array}$ & $\begin{array}{c}0.164 \\
(0.016)^{* * *}\end{array}$ \\
\hline TE & $\begin{array}{r}0.022 \\
(0.016)\end{array}$ & $\begin{array}{l}-0.051 \\
(0.019)^{* * * *}\end{array}$ & $\begin{array}{r}0.016 \\
(0.019)\end{array}$ & $\begin{array}{c}0.048 \\
(0.019)^{* *}\end{array}$ & $\begin{array}{r}0.050 \\
(0.060)\end{array}$ & $\begin{array}{r}0.008 \\
(0.074)\end{array}$ & $\begin{array}{c}0.134 \\
(0.068)^{*}\end{array}$ & $\begin{array}{c}0.215 \\
(0.069)^{* * *}\end{array}$ \\
\hline LFundage & $\begin{array}{l}-0.032 \\
(0.001)^{* * * *}\end{array}$ & $\begin{array}{l}-0.015 \\
(0.002)^{* * *}\end{array}$ & $\begin{array}{l}-0.016 \\
(0.002)^{* * *}\end{array}$ & $\begin{array}{l}-0.016 \\
(0.002)^{* * *}\end{array}$ & $\begin{array}{l}-0.010 \\
(0.003)^{* * * *}\end{array}$ & $\begin{array}{l}-0.014 \\
(0.004)^{* * * *}\end{array}$ & $\begin{array}{l}-0.010 \\
(0.004)^{* *}\end{array}$ & $\begin{array}{l}-0.012 \\
(0.004)^{* * * *}\end{array}$ \\
\hline LAssetsize & $\begin{array}{l}-0.007 \\
(0.000)^{* * * *}\end{array}$ & $\begin{array}{l}-0.006 \\
(0.000)^{* * *}\end{array}$ & $\begin{array}{l}-0.006 \\
(0.000)^{* * *}\end{array}$ & $\begin{array}{l}-0.006 \\
(0.000)^{* * *}\end{array}$ & $\begin{array}{l}-0.004 \\
(0.002)^{* *}\end{array}$ & $\begin{array}{l}-0.005 \\
(0.002)^{* * *}\end{array}$ & $\begin{array}{l}-0.006 \\
(0.002)^{* * *}\end{array}$ & $\begin{array}{l}-0.006 \\
(0.002)^{* * * *}\end{array}$ \\
\hline Yeardummy & $\begin{array}{c}0.002 \\
(0.000)^{* * * *}\end{array}$ & $\begin{array}{c}0.003 \\
(0.000)^{* * *}\end{array}$ & $\begin{array}{c}0.003 \\
(0.000)^{* * * *}\end{array}$ & $\begin{array}{c}0.003 \\
(0.000)^{* * *}\end{array}$ & $\begin{array}{l}-0.000 \\
(0.000)^{* * *}\end{array}$ & $\begin{array}{r}0.000 \\
(0.001)\end{array}$ & $\begin{array}{r}0.001 \\
(0.001)\end{array}$ & $\begin{array}{r}0.001 \\
(0.001)\end{array}$ \\
\hline $\operatorname{Adj}-R^{2}$ & 0.057 & 0.065 & 0.063 & 0.063 & 0.031 & 0.054 & 0.059 & 0.059 \\
\hline Sample & 190,331 & 119,772 & 119,772 & 119,772 & 6,739 & 3,787 & 3,787 & 3,787 \\
\hline
\end{tabular}


한국증권학회지 제48권 5호 (2019)

〈표 4>6개월 자료를 사용한 과거 성과와 현금흐름의 관계 분석

Flow $_{\mathrm{i}, \mathrm{t}}=\mathrm{a}^{+} \mathrm{b}_{1}$ Performance $_{\mathrm{i}, \mathrm{t}-1}+\mathrm{b}_{2}$ LFamilysize $_{\mathrm{i}, \mathrm{t}}+\mathrm{b}_{3}$ Annualvol $_{\mathrm{i}, \mathrm{t}}+\mathrm{b}_{4} \mathrm{ICI}_{\mathrm{i}, \mathrm{t}}+\mathrm{b}_{5} \mathrm{Flow}_{\mathrm{i}, \mathrm{t}-1}+\mathrm{b}_{6} \mathrm{TE}_{\mathrm{i}, \mathrm{t}}+\mathrm{b}_{7} \mathrm{LFundage}_{\mathrm{i}, \mathrm{t}}$ $+\mathrm{b}_{8}$ LAssetsize $_{\mathrm{i}, \mathrm{t}}+\mathrm{b}_{9}$ Yeardummy $\mathrm{i}_{\mathrm{i},}+\mathrm{e}_{\mathrm{i}, \mathrm{t}}$ (OLS 회귀분석 모형)

Flow $_{\mathrm{i}, \mathrm{L}}$ 는 펀드 $\mathrm{i}$ 의 $\mathrm{t}$ 시점에서의 현금흐름이고, Performancei,t-1는 펀드 $\mathrm{i}$ 의 $\mathrm{t}-1$ 의 수익률이다. LFamilysizei,t는 펀드 $\mathrm{i}$ 의 자산운용사가 운용하는 전체 펀드들의 순자산 총액(6개월 평균)의 로그 값이며, Annualvolit는 펀드 $\mathrm{i}$ 의 과거 12 개월간 주간수익률의 표준편차(6개월 평균), $\mathrm{ICI}_{\mathrm{i}, \mathrm{t}}$ 는 펀드 $\mathrm{i}$ 의 $\mathrm{t}$ 시점에서의 산업집중도(6개월 평균)이고, $\mathrm{Flow}_{\mathrm{i}, \mathrm{t}-1}$ 는 펀드 $\mathrm{i}$ 의 전기 현금흐름, $\mathrm{TE}_{\mathrm{i}, \mathrm{L}}$ 는 펀드 $\mathrm{i}$ 의 $\mathrm{t}$ 시점에서의 트레킹에러(6개월 평균)이다. LFundage $\mathrm{i}$ 는 펀드 $\mathrm{i}$ 의 $\mathrm{t}$ 시점에서의 펀드연령(6개월 평균)의 로그 값이고, LAssetsize $\mathrm{i}_{\mathrm{i}, \mathrm{L}}$ 펀드 $\mathrm{i}$ 의 $\mathrm{t}$ 시점에서의 순자산(6개월 평균)의 로그 값이며, Yeardummy $y_{i, t}$ 은 연도 더미다. 괄호 안은 cluster robust 표준 오차이며 유의확률 $1 \%, 5 \%, 10 \%$ 수준에 대하여 각각 ${ }^{* * *},{ }^{* *}$, *로 표시하였다.

\begin{tabular}{|c|c|c|c|c|c|c|c|c|}
\hline \multirow[b]{2}{*}{ 설명변수 } & \multicolumn{4}{|c|}{ 공모 주식펀드 } & \multicolumn{4}{|c|}{ 연기금 위탁주식펀드 } \\
\hline & $\begin{array}{l}\mathrm{BM} \\
\text { 초과 }\end{array}$ & $\begin{array}{l}\text { Jensen } \\
\text { 알파 }\end{array}$ & $\begin{array}{l}\mathrm{F}-\mathrm{F} \\
\text { 알파 }\end{array}$ & $\begin{array}{c}\text { Carhart } \\
\text { 알파 }\end{array}$ & $\begin{array}{l}\mathrm{BM} \\
\text { 초과 }\end{array}$ & $\begin{array}{l}\text { Jensen } \\
\text { 알파 }\end{array}$ & $\begin{array}{l}\mathrm{F}-\mathrm{F} \\
\text { 알파 }\end{array}$ & $\begin{array}{l}\text { Carhart } \\
\text { 알파 }\end{array}$ \\
\hline Performance & $\begin{array}{c}1.488 \\
(0.176)^{* * * *}\end{array}$ & $\begin{array}{c}8.174 \\
(0.528)^{* * * *}\end{array}$ & $\begin{array}{c}6.711 \\
(0.498)^{* * * *}\end{array}$ & $\begin{array}{c}6.141 \\
(0.502)^{* * * *}\end{array}$ & $\begin{array}{c}1.724 \\
(0.388)^{* * *}\end{array}$ & $\begin{array}{c}3.535 \\
(1.168)^{* * * *}\end{array}$ & $\begin{array}{c}3.956 \\
(1.114)^{* * * *}\end{array}$ & $\begin{array}{c}4.266 \\
(1.141)^{* * * *}\end{array}$ \\
\hline LFamilysize & $\begin{array}{c}0.058 \\
(0.010)^{* * * *}\end{array}$ & $\begin{array}{r}0.003 \\
(0.012)\end{array}$ & $\begin{array}{r}0.003 \\
(0.012)\end{array}$ & $\begin{array}{r}0.006 \\
(0.012)\end{array}$ & $\begin{array}{c}0.036 \\
(0.018)^{* *}\end{array}$ & $\begin{array}{r}0.002 \\
(0.021)\end{array}$ & $\begin{array}{r}0.006 \\
(0.020)\end{array}$ & $\begin{array}{r}0.005 \\
(0.020)\end{array}$ \\
\hline Annualvol & $\begin{array}{r}0.196 \\
(0.156)\end{array}$ & $\begin{array}{c}0.559 \\
(0.202)^{* * *}\end{array}$ & $\begin{array}{c}0.634 \\
(0.202)^{* * * *}\end{array}$ & $\begin{array}{c}0.613 \\
(0.202)^{* * * *}\end{array}$ & $\begin{array}{l}-0.138 \\
(0.270)\end{array}$ & $\begin{array}{l}-0.971 \\
(0.285)^{* * *}\end{array}$ & $\begin{array}{l}-0.972 \\
(0.284)^{* * *}\end{array}$ & $\begin{array}{l}-1.026 \\
(0.285)^{* * * *}\end{array}$ \\
\hline ICI & $\begin{array}{l}-0.037 \\
(0.055)\end{array}$ & $\begin{array}{r}0.034 \\
(0.068)\end{array}$ & $\begin{array}{l}-0.026 \\
(0.069)\end{array}$ & $\begin{array}{l}-0.061 \\
(0.069)\end{array}$ & $\begin{array}{l}-0.805 \\
(0.232)^{* * *}\end{array}$ & $\begin{array}{l}-2.622 \\
(0.976)^{* *}\end{array}$ & $\begin{array}{l}-1.744 \\
(0.884)^{* *}\end{array}$ & $\begin{array}{l}-1.300 \\
(0.876)\end{array}$ \\
\hline Flow $(\mathrm{t}-1)$ & $\begin{array}{c}0.064 \\
(0.006)^{* * * *}\end{array}$ & $\begin{array}{c}0.108 \\
(0.008)^{* * *}\end{array}$ & $\begin{array}{c}0.113 \\
(0.008)^{* * * *}\end{array}$ & $\begin{array}{c}0.116 \\
(0.008)^{* * * *}\end{array}$ & $\begin{array}{c}0.102 \\
(0.037)^{* * *}\end{array}$ & $\begin{array}{c}0.311 \\
(0.070)^{* * *}\end{array}$ & $\begin{array}{c}0.297 \\
(0.070)^{* * * *}\end{array}$ & $\begin{array}{c}0.297 \\
(0.070)^{* * * *}\end{array}$ \\
\hline TE & $\begin{array}{c}0.944 \\
(0.290)^{* * * *}\end{array}$ & $\begin{array}{r}0.029 \\
(0.330)\end{array}$ & $\begin{array}{c}0.576 \\
(0.327)^{*}\end{array}$ & $\begin{array}{c}0.908 \\
(0.327)^{* * *}\end{array}$ & $\begin{array}{l}-0.543 \\
(0.760)\end{array}$ & $\begin{array}{l}-0.198 \\
(0.862)\end{array}$ & $\begin{array}{r}0.592 \\
(0.835)\end{array}$ & $\begin{array}{r}0.945 \\
(0.844)\end{array}$ \\
\hline LFundage & $\begin{array}{l}-0.264 \\
(0.017)^{* * * *}\end{array}$ & $\begin{array}{l}-0.022 \\
(0.030)\end{array}$ & $\begin{array}{l}-0.039 \\
(0.030)\end{array}$ & $\begin{array}{l}-0.033 \\
(0.030)\end{array}$ & $\begin{array}{l}-0.063 \\
(0.039)\end{array}$ & $\begin{array}{l}-0.073 \\
(0.051)\end{array}$ & $\begin{array}{l}-0.050 \\
(0.052)\end{array}$ & $\begin{array}{l}-0.057 \\
(0.051)\end{array}$ \\
\hline LAssetsize & $\begin{array}{l}-0.099 \\
(0.003)^{* * * *}\end{array}$ & $\begin{array}{l}-0.086 \\
(0.004)^{* * * *}\end{array}$ & $\begin{array}{l}-0.082 \\
(0.004)^{* * * *}\end{array}$ & $\begin{array}{l}-0.082 \\
(0.004)^{* * *}\end{array}$ & $\begin{array}{l}-0.108 \\
(0.022)^{* * *}\end{array}$ & $\begin{array}{l}-0.113 \\
(0.022)^{* * *}\end{array}$ & $\begin{array}{l}-0.112 \\
(0.022)^{* * *}\end{array}$ & $\begin{array}{l}-0.110 \\
(0.022)^{* * * *}\end{array}$ \\
\hline Yeardummy & $\begin{array}{c}0.010 \\
(0.004)^{* *}\end{array}$ & $\begin{array}{c}0.034 \\
(0.006)^{* * * *}\end{array}$ & $\begin{array}{c}0.036 \\
(0.006)^{* * * *}\end{array}$ & $\begin{array}{c}0.037 \\
(0.007)^{* * *}\end{array}$ & $\begin{array}{r}0.006 \\
(0.007)\end{array}$ & $\begin{array}{r}0.009 \\
(0.009)\end{array}$ & $\begin{array}{r}0.007 \\
(0.008)\end{array}$ & $\begin{array}{r}0.010 \\
(0.009)\end{array}$ \\
\hline $\operatorname{Adj}-R^{2}$ & 0.058 & 0.057 & 0.054 & 0.052 & 0.082 & 0.115 & 0.121 & 0.123 \\
\hline Sample & 26,647 & 15,500 & 15,500 & 15,500 & 931 & 499 & 499 & 499 \\
\hline
\end{tabular}

현금흐름과 다른 통제변수들 간의 상관관계를 살펴보면 현금흐름과 펀드 수익률의 변동성 (Annualvol)과의 관계는 일반적으로 공모펀드의 경우에는 양의 상관관계, 연기금 위탁펀드의 경우에는 음의 상관관계를 보이고 있다. 현금흐름과 산업집중도(ICI)와의 관계는 일반적으로 연기금 위탁펀드의 경우에만 음의 상관관계를 보이고 있다. 현금흐름과 펀드의 전기 현금흐름과의 관계는 일반적으로 공모펀드와 연기금 위탁펀드의 경우 모두 통계적으로 유의한 양의 상관관계를 보이고 있다. 현금흐름과 트레킹에러(TE)와의 관계는 연 자료를 사용한 공모펀드의 경우에만 통계적으로 유의한 양의 상관관계를 보이고 있다. 현금흐름과 펀드연령(LFundage)과의 관계는 월별 자료를 사용한 공모펀드와 연기금 위탁펀드의 경우에만 모두 통계적으로 유의한 음의 상관관계를 보이고 있다. 이와 같은 결과들은 일반적으로 기존 연구들의 결과와 비슷한 결과를 나타내고 있다(Chevalier and Ellison, 1997; Sirri and Tufano, 1998; Del Guercio and Tkac, 2002; Ferreira et al., 2012; Spiegel and Zhang, 2013; Paek and Ko, 2016). 
Comparative Analysis on the Flow-Performance Relationship between Public Equity and Fiduciary Pension Funds

〈표 5〉연 자료를 사용한 과거 성과와 현금흐름의 관계 분석

Flow $_{\mathrm{i}, \mathrm{t}}=\mathrm{a}^{+} \mathrm{b}_{1}$ Performance $_{\mathrm{i}, \mathrm{t}-1}+\mathrm{b}_{2}$ LFamilysize $_{\mathrm{i}, \mathrm{t}}+\mathrm{b}_{3}$ Annualvol $_{\mathrm{i}, \mathrm{t}}+\mathrm{b}_{4} \mathrm{ICI}_{\mathrm{i}, \mathrm{t}}+\mathrm{b}_{5}$ Flow $_{\mathrm{i}, \mathrm{t}-1}+\mathrm{b}_{6} \mathrm{TE}_{\mathrm{i}, \mathrm{t}}+\mathrm{b}_{7} \mathrm{LFundage}_{\mathrm{i}, \mathrm{t}}$ $+\mathrm{b}_{8}$ LAssetsize $\mathrm{e}_{\mathrm{i}, \mathrm{t}}+\mathrm{b}_{9}$ Yeardummy $\mathrm{i}_{\mathrm{t}, \mathrm{t}}+\mathrm{e}_{\mathrm{i}, \mathrm{t}}$ (OLS 회귀분석 모형)

Flowi,t는 펀드 $\mathrm{i}$ 의 $\mathrm{t}$ 시점에서의 현금흐름이고, Performancei,t-1는 펀드 $\mathrm{i}$ 의 $\mathrm{t}-1$ 년의 수익률이다. LFamilysize, 는 펀드 $\mathrm{i}$ 의 자산운용사가 운용하는 전체 펀드들의 순자산 총액(연평균)의 로그 값이며, Annualvoli, 는 펀드 $\mathrm{i}$ 의 과거 12 개월간 주간수익률의 표준편차(연평균), $\mathrm{ICl}_{\mathrm{i},}$ 는 펀드 $\mathrm{i}$ 의 $\mathrm{t}$ 시점에서의 산업집중도(연평균)이고, $\mathrm{Flow}_{\mathrm{it}-1}$ 는 펀드 $\mathrm{i}$ 의 전년 현금흐름, $\mathrm{TE}_{\mathrm{i}, \mathrm{t}}$ 는 펀드 $\mathrm{i}$ 의 $\mathrm{t}$ 시점에서의 트레킹에러(연평균)이다. LFundage $\mathrm{i}, \mathrm{t}$ 는 펀드 $\mathrm{i}$ 의 $\mathrm{t}$ 시점에서의 펀드연령(연평균)의 로그 값이고, LAssetsize $\mathrm{i}_{\mathrm{i}, \mathrm{L}}$ 펀드 $\mathrm{i}$ 의 t시점에서의 순자산(연평균)의 로그 값이며, Yeardummy $\mathrm{i}_{\mathrm{i}, \mathrm{L}}$ 는 연도 더미다. 괄호 안은 cluster robust 표준 오차이며 유의확률 $1 \%, 5 \%, 10 \%$ 수준에 대하여 각각 ${ }^{* * *},{ }^{* *}$, *로 표시하였다.

\begin{tabular}{|c|c|c|c|c|c|c|c|c|}
\hline \multirow[b]{2}{*}{ 설명변수 } & \multicolumn{4}{|c|}{ 공모 주식펀드 } & \multicolumn{4}{|c|}{ 연기금 위탁주식펀드 } \\
\hline & $\begin{array}{l}\mathrm{BM} \\
\text { 초과 }\end{array}$ & $\begin{array}{l}\text { Jensen } \\
\text { 알파 }\end{array}$ & $\begin{array}{l}\mathrm{F}-\mathrm{F} \\
\text { 알파 }\end{array}$ & $\begin{array}{c}\text { Carhart } \\
\text { 알파 }\end{array}$ & $\begin{array}{l}\mathrm{BM} \\
\text { 초과 }\end{array}$ & $\begin{array}{l}\text { Jensen } \\
\text { 알파 }\end{array}$ & $\begin{array}{l}\mathrm{F}-\mathrm{F} \\
\text { 알파 }\end{array}$ & $\begin{array}{l}\text { Carhart } \\
\text { 알파 }\end{array}$ \\
\hline Performance & $\begin{array}{c}3.697 \\
(0.349)^{* * * *}\end{array}$ & $\begin{array}{l}10.938 \\
(0.863)^{* * * *}\end{array}$ & $\begin{array}{c}8.255 \\
(0.783)^{* * * *}\end{array}$ & $\begin{array}{c}7.335 \\
(0.801)^{* * *}\end{array}$ & $\begin{array}{c}2.510 \\
(0.669)^{* * *}\end{array}$ & $\begin{array}{c}4.323 \\
(2.010)^{* *}\end{array}$ & $\begin{array}{r}1.834 \\
(2.007)\end{array}$ & $\begin{array}{c}3.782 \\
(2.070)^{*}\end{array}$ \\
\hline LFamilysize & $\begin{array}{c}0.120 \\
(0.031)^{* * *}\end{array}$ & $\begin{array}{r}0.013 \\
(0.042)\end{array}$ & $\begin{array}{r}0.026 \\
(0.042)\end{array}$ & $\begin{array}{r}0.037 \\
(0.042)\end{array}$ & $\begin{array}{r}0.031 \\
(0.048)\end{array}$ & $\begin{array}{r}0.006 \\
(0.070)\end{array}$ & $\begin{array}{r}0.036 \\
(0.069)\end{array}$ & $\begin{array}{r}0.023 \\
(0.069)\end{array}$ \\
\hline Annualvol & $\begin{array}{c}0.993 \\
(0.494)^{* *}\end{array}$ & $\begin{array}{c}1.300 \\
(0.733)^{*}\end{array}$ & $\begin{array}{c}1.333 \\
(0.736)^{*}\end{array}$ & $\begin{array}{r}1.173 \\
(0.738)\end{array}$ & $\begin{array}{l}-1.043 \\
(0.760)\end{array}$ & $\begin{array}{l}-1.943 \\
(1.040)^{*}\end{array}$ & $\begin{array}{l}-1.878 \\
(1.050)^{*}\end{array}$ & $\begin{array}{l}-2.062 \\
(1.049)^{*}\end{array}$ \\
\hline ICI & $\begin{array}{l}-0.051 \\
(0.165)\end{array}$ & $\begin{array}{l}-0.027 \\
(0.224)\end{array}$ & $\begin{array}{l}-0.208 \\
(0.225)\end{array}$ & $\begin{array}{l}-0.279 \\
(0.226)\end{array}$ & $\begin{array}{l}-2.661 \\
(1.237)^{* *}\end{array}$ & $\begin{array}{l}-8.356 \\
(3.289)^{* *}\end{array}$ & $\begin{array}{l}-5.517 \\
(2.981)^{*}\end{array}$ & $\begin{array}{l}-4.918 \\
(2.917)^{*}\end{array}$ \\
\hline Flow $(t-1)$ & $\begin{array}{c}0.054 \\
(0.011)^{* * * *}\end{array}$ & $\begin{array}{c}0.061 \\
(0.014)^{* * * *}\end{array}$ & $\begin{array}{c}0.070 \\
(0.014)^{* * *}\end{array}$ & $\begin{array}{c}0.076 \\
(0.014)^{* * * *}\end{array}$ & $\begin{array}{r}0.051 \\
(0.040)\end{array}$ & $\begin{array}{c}0.263 \\
(0.146)^{*}\end{array}$ & $\begin{array}{c}0.273 \\
(0.151)^{*}\end{array}$ & $\begin{array}{r}0.240 \\
(0.150)\end{array}$ \\
\hline TE & $\begin{array}{c}2.830 \\
(0.871)^{* * *}\end{array}$ & $\begin{array}{c}2.378 \\
(1.069)^{* *}\end{array}$ & $\begin{array}{c}3.272 \\
(1.071)^{* * *}\end{array}$ & $\begin{array}{c}3.920 \\
(1.076)^{* * * *}\end{array}$ & $\begin{array}{r}1.429 \\
(2.032)\end{array}$ & $\begin{array}{l}-1.075 \\
(2.855)\end{array}$ & $\begin{array}{r}0.653 \\
(2.820)\end{array}$ & $\begin{array}{r}1.556 \\
(2.859)\end{array}$ \\
\hline LFundage & $\begin{array}{l}-0.100 \\
(0.066)\end{array}$ & $\begin{array}{l}-0.021 \\
(0.110)\end{array}$ & $\begin{array}{l}-0.096 \\
(0.110)\end{array}$ & $\begin{array}{l}-0.082 \\
(0.110)\end{array}$ & $\begin{array}{l}-0.158 \\
(0.125)^{* * *}\end{array}$ & $\begin{array}{l}-0.139 \\
(0.184)\end{array}$ & $\begin{array}{l}-0.149 \\
(0.188)\end{array}$ & $\begin{array}{l}-0.144 \\
(0.185)\end{array}$ \\
\hline LAssetsize & $\begin{array}{l}-0.229 \\
(0.010)^{* * *}\end{array}$ & $\begin{array}{l}-0.248 \\
(0.013)^{* * *}\end{array}$ & $\begin{array}{l}-0.239 \\
(0.013)^{* * * *}\end{array}$ & $\begin{array}{l}-0.238 \\
(0.013)^{* * *}\end{array}$ & $\begin{array}{l}-0.289 \\
(0.055)^{* * *}\end{array}$ & $\begin{array}{l}-0.450 \\
(0.075)^{* * * *}\end{array}$ & $\begin{array}{l}-0.422 \\
(0.075)^{* * *}\end{array}$ & $\begin{array}{l}-0.428 \\
(0.074)^{* * *}\end{array}$ \\
\hline Yeardummy & $\begin{array}{c}0.024 \\
(0.013)^{*}\end{array}$ & $\begin{array}{c}0.105 \\
(0.023)^{* * * *}\end{array}$ & $\begin{array}{c}0.092 \\
(0.023)^{* * *}\end{array}$ & $\begin{array}{c}0.092 \\
(0.023)^{* * *}\end{array}$ & $\begin{array}{c}0.045 \\
(0.017)^{* * *}\end{array}$ & $\begin{array}{c}0.061 \\
(0.033)^{*}\end{array}$ & $\begin{array}{r}0.038 \\
(0.031)\end{array}$ & $\begin{array}{r}0.052 \\
(0.032)\end{array}$ \\
\hline $\operatorname{Adj}-R^{2}$ & 0.068 & 0.082 & 0.075 & 0.071 & 0.163 & 0.180 & 0.164 & 0.175 \\
\hline Sample & 10,117 & 6,299 & 6,299 & 6,299 & 330 & 195 & 195 & 195 \\
\hline
\end{tabular}

\section{3 공모펀드와 연기금 위탁펀드의 성과와 현금흐름 관계 비교 분석: 단계적 선형 회귀분석(Piecewise Regression)}

이제 본 연구는 공모펀드와 연기금 위탁펀드의 성과와 현금흐름 관계를 분석한 기존 연구와의 비교를 위해 OLS로 단계적 선형 회귀분석 모형을 추정하여 과거 성과와 현금흐름의 관계를 검증하고자 한다. 종속변수는 위에서 정의한 현금흐름이며, 독립변수로는 벤치마크 대비 초과 수익률, Jensen 알파, Fama-French 알파, 그리고 Carhart 알파의 네 개의 성과평가지표를 사용하여 각각의 성과평가지표에 대해 단계적 회귀분석을 실시하였다. 또한 공통적으로 개별 펀드의 현금흐름에 영향을 줄 수 있는 펀드 특성을 통제 변수로 사용하였다.

$$
\begin{aligned}
\text { Flow }_{\mathrm{i}, \mathrm{t}}= & \mathrm{a}+\mathrm{b}_{1} \text { Low }_{\mathrm{i}, \mathrm{t}-1}+\mathrm{b}_{2} \mathrm{Mid}_{\mathrm{i},-\mathrm{-}-1}+\mathrm{b}_{3} \text { High }_{\mathrm{i}, \mathrm{t}-1}+\mathrm{b}_{4} \mathrm{LFamilysize}_{\mathrm{i}, \mathrm{t}}+\mathrm{b}_{5} \text { Annualvol }_{\mathrm{i}, \mathrm{t}}+\mathrm{b}_{6} \mathrm{ICI}_{\mathrm{i}, \mathrm{t}} \\
& +\mathrm{b}_{7} \text { Flow }_{\mathrm{i}, \mathrm{t}-1}+\mathrm{b}_{8} \text { TE }_{\mathrm{i}, \mathrm{t}}+\mathrm{b}_{9} \text { LFundage }_{\mathrm{i}, \mathrm{t}}+\mathrm{b}_{10} \mathrm{LAssetsize}_{\mathrm{i}, \mathrm{t}}+\mathrm{b}_{11} \text { Yeardummy }_{\mathrm{i}, \mathrm{t}}+\mathrm{e}_{\mathrm{i}, \mathrm{t}}
\end{aligned}
$$


한국증권학회지 제48권 5호 (2019)

$\mathrm{Flow}_{\mathrm{i}, \mathrm{t}}$ 는 펀드 $\mathrm{i}$ 의 $\mathrm{t}$ 시점에서의 현금흐름이고, $\mathrm{Rank}_{\mathrm{i}, \mathrm{t}-1}$ 는 펀드 $\mathrm{i}$ 의 $\mathrm{t}-1$ 의 수익률을 기준으로 펀드 유형별로 0 부터 1 까지 부여된 순위이다. $\mathrm{Low}_{\mathrm{i}, \mathrm{t}-1}$ 는 Rank $\mathrm{k}_{\mathrm{i}, \mathrm{t}-1}$ 과 0.2 중 최소값이고, $\mathrm{Midi}_{\mathrm{i}, \mathrm{t}-1}$ 는 Rank $_{\mathrm{i}, \mathrm{t}-1}-\mathrm{Low}_{\mathrm{i}, \mathrm{t}-1}$ 과 0.6 중 최소값이며, High, $\mathrm{h}_{\mathrm{i},-1}$ 는 Rank $\mathrm{R}_{\mathrm{i}, \mathrm{t}-1}-\mathrm{Low}_{\mathrm{i}, \mathrm{t}-1}-\mathrm{Mid}_{\mathrm{i}, \mathrm{t}-1}$ 이다. LFamilysizi, 펀드 $\mathrm{i}$ 의 자산운용사가 운용하는 전체 펀드들의 순자산 총액의 로그 값이며, Annualvolit,는 펀드 $\mathrm{i}$ 의 과거 12 개월간 주간수익률의 표준편차, $\mathrm{ICI}_{\mathrm{i}, \mathrm{t}}$ 는 펀드 $\mathrm{i}$ 의 $\mathrm{t}$ 시점에서의 산업집중도이고, Flow $_{\mathrm{i}, \mathrm{t}-1}$ 는 펀드 $\mathrm{i}$ 의 전기 현금흐름, $\mathrm{TE}_{\mathrm{i}, \mathrm{t}}$ 는 펀드 $\mathrm{i}$ 의 $\mathrm{t}$ 시점에서의 트레킹에러이다. LFundage $\mathrm{i}_{\mathrm{i}, \mathrm{L}}$ 는 펀드 $\mathrm{i}$ 의 $\mathrm{t}$ 시점에서의 펀드연령(월)의 로그 값이고, LAssetsize $\mathrm{H}_{\mathrm{t}}$ 는 펀드 $\mathrm{i}$ 의 $\mathrm{t}$ 시점에서의 순자산의 로그 값이며, Yeardummy $\mathrm{i}_{\mathrm{i}, \mathrm{t}}$ 는 연도 더미다.

본 연구는 벤치마크 대비 초과수익률, Jensen 알파, Fama-French 알파, 그리고 Carhart 알파를 사용하여 펀드의 성과 순위를 부여하고, 성과에 대한 현금흐름의 볼록성을 검증하고자 한다. 성과 순위는 모든 기간에서 동일하게 0 부터 1 까지의 범위를 가지기 때문에 개별 펀드 수익률의 극단 값이 큰 영향을 주기 어렵다. 본 연구의 관심이 되는 볼록성은 독립변수 Low(하위 성과그룹), $\operatorname{Mid}($ 중간 성과그룹), $\operatorname{High}$ (상위 성과그룹)의 계수 값과 그들 간의 차이로 검증할 수 있다.

<표 6>, <표 7>, <표 8>에는 각각 월별 자료, 6개월 자료, 연 자료를 이용한 단계적 선형 회귀분석 결과가 제시되어 있다. 모든 자료에 대해 공모펀드와 연기금 위탁펀드에 공통적으로 나타나는 결과는 현금흐름과 펀드의 크기와는 통계적으로 유의한 음의 상관관계가 있다는 것이다.

현금흐름과 다른 통제변수들 간의 상관관계를 살펴보면 현금흐름과 펀드 수익률의 변동성 (Annualvol)과의 관계는 일반적으로 공모펀드의 경우에는 양의 상관관계, 연기금 위탁펀드의 경우에는 음의 상관관계를 보이고 있다. 현금흐름과 산업집중도(ICI)와의 관계는 일반적으로 연기금 위탁펀드의 경우에만 음의 상관관계를 보이고 있다. 현금흐름과 펀드의 전기 현금흐름과의 관계는 연 자료를 사용한 연기금 위탁펀드의 경우를 제외하고는 일반적으로 공모펀드와 연기금 위탁펀드의 경우 모두 통계적으로 유의한 양의 상관관계를 보이고 있다. 현금흐름과 펀드연령 (LFundage)과의 관계는 월별 자료를 사용한 공모펀드와 연기금 위탁펀드의 경우에만 모두 통계적으로 유의한 음의 상관관계를 보이고 있다. 이와 같은 결과들은 일반적으로 2절에서 행한 OLS 회귀분석 결과와 비슷한 결과를 나타내고 있다.

다음은 본 연구의 관심이 되는 과거 성과와 현금흐름의 관계가 볼록성을 나타내는지를 알아 보고자 한다. 공모펀드의 경우 모든 자료에서 전기의 성과가 우수한 High 그룹에 대해 전기의 성과와 현금흐름은 통계적으로 유의한 양의 상관관계를 보이고 있다. 전기의 성과가 보통인 $\mathrm{Mid}$ 그룹에 대해서도 6 개월 자료의 $\mathrm{BM}$ 초과수익률의 경우를 제외하고는 모든 자료에서 성과에 대한 계수가 High 그룹에 비해서 현저히 낮긴 하지만 전기의 성과와 현금흐름은 통계적으로 유의한 양의 상관관계를 보이고 있다. 그러나 Low 그룹에 대해서는 전기의 성과와 현금흐름 간에 일관성 있게 통계적으로 유의한 관계를 확인할 수 없었다.

이 같은 결과는 공모펀드의 경우 전기 성과와 현금흐름 간에는 볼록성의 관계가 존재한다는 것을 암시하지만 볼록성의 존재 여부를 좀 더 명확히 검증하기 위해서 High, Mid, Low의 계수간의 차이 검증을 하여야 한다. 모든 자료에서 성과지표 중 $\mathrm{BM}$ 초과수익률과 Jensen 알파에 대해서 High 그룹과 Mid 그룹의 차이와 High 그룹과 Low 그룹의 차이는 통계적으로 
Comparative Analysis on the Flow-Performance Relationship between Public Equity and Fiduciary Pension Funds

유의한 양의 차이를 보이고 있는 반면 모든 자료에서 Mid 그룹과 Low 그룹의 차이는 없는 것으로 나타났다. 이는 전기 성과와 현금흐름 간에는 볼록성의 관계가 있다는 공모펀드에 대한 기존 연구 결과와 같은 결과이다(Chevalier and Ellison, 1997; Sirri and Tufano, 1998; Ferreira et al., 2012; Spiegel and Zhang, 2013; Paek and Ko, 2016).

〈표 6〉월별 자료를 사용한 과거 성과와 현금흐름의 관계 분석

Flow $_{\mathrm{i}, \mathrm{t}}=\mathrm{a}^{+} \mathrm{b}_{1} \mathrm{Low}_{\mathrm{i}, \mathrm{t}-1}+\mathrm{b}_{2} \mathrm{Mid}_{\mathrm{i}, \mathrm{t}-1}+\mathrm{b}_{3} \mathrm{High}_{\mathrm{i}, \mathrm{t}-1}+\mathrm{b}_{4} \mathrm{LFamilysize}_{\mathrm{i}, \mathrm{t}}+\mathrm{b}_{5}$ Annualvol $_{\mathrm{i}, \mathrm{t}}+\mathrm{b}_{6} \mathrm{ICI}_{\mathrm{i}, \mathrm{t}}+\mathrm{b}_{7} \mathrm{Flow}_{\mathrm{i}, \mathrm{t}-\mathrm{1}}+\mathrm{b}_{8} \mathrm{TE}_{\mathrm{i}, \mathrm{t}}$ $+b_{9} L F$ undage $e_{i, t}+b_{10} L A$ ssetsize $\mathrm{i}_{i, t}+b_{11}$ Yeardummy $_{i, t}+e_{i, t}$ (단계적 회귀분석 모형)

Flow $_{\mathrm{i}, \mathrm{L}}$ 는 펀드 $\mathrm{i}$ 의 $\mathrm{t}$ 시점에서의 현금흐름이고, Ranki,t-1는 펀드 $\mathrm{i}$ 의 $\mathrm{t}-1$ 의 수익률을 기준으로 펀드 유형별로 0 부터 1 까지 부여된 순위이다. $\mathrm{Low}_{\mathrm{i}, \mathrm{t}-1}$ 는 Rank $\mathrm{R}_{\mathrm{i}, \mathrm{t}-1}$ 과 0.2 중 최소값이고, $\mathrm{Mid}_{\mathrm{i}, \mathrm{t}-1}$ 는 Rank $\mathrm{R}_{\mathrm{i}, \mathrm{t}-1}-\mathrm{Low}_{\mathrm{i}, \mathrm{t}-1}$ 과 0.6 중 최소값이며, $\mathrm{High}_{\mathrm{i}, \mathrm{t}-1}$ 는 Rank $_{\mathrm{i},-1}-\mathrm{Low}_{\mathrm{i},-1}-\mathrm{Mid}_{\mathrm{i},-1}$ 이다. LFamilysize $\mathrm{i}_{1, \mathrm{~L}}$ 넌 펀드 $\mathrm{i}$ 의 자산운용사가 운용하는 전체 펀드들의 순자산 총액의 로그 값이며, Annualvoli,t는 펀드 $\mathrm{i}$ 의 과거 12 개월간 주간수익률의 표준편차, $\mathrm{ICI}_{\mathrm{i}, \mathrm{t}}$ 는 펀드 $\mathrm{i}$ 의 $\mathrm{t}$ 시점에서의 산업집중도이고, $\mathrm{Flow}_{\mathrm{i}, \mathrm{t}-1}$ 는 펀드 $\mathrm{i}$ 의 전월 현금흐름, $\mathrm{TE}_{\mathrm{i}, t}$ 는 펀드 $\mathrm{i}$ 의 $\mathrm{t}$ 시점에서의 트레킹에러이다. LFundage, 는 펀드 $\mathrm{i}$ 의 $\mathrm{t}$ 시점에서의 펀드연령(월)의 로그 값이고, LAssetsize $\mathrm{i}, \mathrm{t}$ 는 펀드 $\mathrm{i}$ 의 t시점에서의 순자산의 로그 값이며, Yeardummy $\mathrm{i}_{\mathrm{i}, \mathrm{L}}$ 은 연도 더미다. 괄호 안은 cluster robust 표준 오차이며 유의확률 $1 \%, 5 \%, 10 \%$ 수준에 대하여 각각 ${ }^{* * *},{ }^{* *},{ }^{*}$ 로 표시하였다.

\begin{tabular}{|c|c|c|c|c|c|c|c|c|}
\hline \multirow[b]{2}{*}{ 설명변수 } & \multicolumn{4}{|c|}{ 공모 주식펀드 } & \multicolumn{4}{|c|}{ 연기금 위탁주식펀드 } \\
\hline & $\begin{array}{l}\mathrm{BM} \\
\text { 초과 }\end{array}$ & $\begin{array}{l}\text { Jensen } \\
\text { 알파 }\end{array}$ & $\begin{array}{l}\mathrm{F}-\mathrm{F} \\
\text { 알파 }\end{array}$ & $\begin{array}{l}\text { Carhart } \\
\text { 알파 }\end{array}$ & $\begin{array}{l}\mathrm{BM} \\
\text { 초과 }\end{array}$ & $\begin{array}{l}\text { Jensen } \\
\text { 알파 }\end{array}$ & $\begin{array}{l}\mathrm{F}-\mathrm{F} \\
\text { 알파 }\end{array}$ & $\begin{array}{l}\text { Carhart } \\
\text { 알파 }\end{array}$ \\
\hline Low & $\begin{array}{r}0.011 \\
(0.016)\end{array}$ & $\begin{array}{r}0.013 \\
(0.020)\end{array}$ & $\begin{array}{c}0.067 \\
(0.019)^{* * *}\end{array}$ & $\begin{array}{c}0.054 \\
(0.019)^{* * *}\end{array}$ & $\begin{array}{c}0.065 \\
(0.031)^{* *}\end{array}$ & $\begin{array}{r}0.078 \\
(0.054)\end{array}$ & $\begin{array}{c}0.149 \\
(0.034)^{* * *}\end{array}$ & $\begin{array}{c}0.143 \\
(0.032)^{* * *}\end{array}$ \\
\hline Mid & $\begin{array}{c}0.010 \\
(0.003)^{* * * *}\end{array}$ & $\begin{array}{c}0.044 \\
(0.005)^{* * *}\end{array}$ & $\begin{array}{c}0.042 \\
(0.005)^{* * *}\end{array}$ & $\begin{array}{c}0.047 \\
(0.005)^{* * *}\end{array}$ & $\begin{array}{r}0.002 \\
(0.008)\end{array}$ & $\begin{array}{c}0.042 \\
(0.013)^{* * *}\end{array}$ & $\begin{array}{c}0.026 \\
(0.009)^{* * *}\end{array}$ & $\begin{array}{c}0.027 \\
(0.009)^{* * *}\end{array}$ \\
\hline High & $\begin{array}{l}0.227 \\
(0.02)^{* * * *}\end{array}$ & $\begin{array}{c}0.224 \\
(0.025)^{* * * *}\end{array}$ & $\begin{array}{c}0.102 \\
(0.026)^{* * *}\end{array}$ & $\begin{array}{c}0.062 \\
(0.025)^{* *}\end{array}$ & $\begin{array}{r}0.063 \\
(0.043)\end{array}$ & $\begin{array}{l}-0.065 \\
(0.041)\end{array}$ & $\begin{array}{r}0.043 \\
(0.030)\end{array}$ & $\begin{array}{c}0.060 \\
(0.034)^{*}\end{array}$ \\
\hline LFamilysize & $\begin{array}{c}0.003 \\
(0.001)^{* * * *}\end{array}$ & $\begin{array}{l}-0.001 \\
(0.001)\end{array}$ & $\begin{array}{l}-0.000 \\
(0.001)\end{array}$ & $\begin{array}{l}-0.000 \\
(0.001)\end{array}$ & $\begin{array}{r}0.003 \\
(0.002)\end{array}$ & $\begin{array}{r}0.001 \\
(0.003)\end{array}$ & $\begin{array}{r}0.001 \\
(0.003)\end{array}$ & $\begin{array}{r}0.001 \\
(0.003)\end{array}$ \\
\hline Annualvol & $\begin{array}{l}0.065 \\
(0.01)^{* * * *}\end{array}$ & $\begin{array}{c}0.099 \\
(0.012)^{* * *}\end{array}$ & $\begin{array}{c}0.106 \\
(0.012)^{* * *}\end{array}$ & $\begin{array}{c}0.105 \\
(0.012)^{* * *}\end{array}$ & $\begin{array}{l}-0.061 \\
(0.025)^{* * *}\end{array}$ & $\begin{array}{l}-0.105 \\
(0.020)^{* * *}\end{array}$ & $\begin{array}{l}-0.112 \\
(0.022)^{* * *}\end{array}$ & $\begin{array}{l}-0.118 \\
(0.022)^{* * * *}\end{array}$ \\
\hline ICI & $\begin{array}{r}0.003 \\
(0.004)\end{array}$ & $\begin{array}{c}0.012 \\
(0.005)^{* *}\end{array}$ & $\begin{array}{c}0.008 \\
(0.005)^{*}\end{array}$ & $\begin{array}{r}0.006 \\
(0.005)\end{array}$ & $\begin{array}{l}-0.054 \\
(0.014)^{* * * *}\end{array}$ & $\begin{array}{l}-0.084 \\
(0.040)^{* * *}\end{array}$ & $\begin{array}{l}-0.076 \\
(0.040)^{*}\end{array}$ & $\begin{array}{l}-0.067 \\
(0.039)^{*}\end{array}$ \\
\hline Flow $(t-1)$ & $\begin{array}{c}0.192 \\
(0.008)^{* * *}\end{array}$ & $\begin{array}{c}0.225 \\
(0.010)^{* * *}\end{array}$ & $\begin{array}{c}0.227 \\
(0.011)^{* * *}\end{array}$ & $\begin{array}{c}0.227 \\
(0.011)^{* * *}\end{array}$ & $\begin{array}{c}0.136 \\
(0.025)^{* * *}\end{array}$ & $\begin{array}{c}0.165 \\
(0.046)^{* * *}\end{array}$ & $\begin{array}{c}0.160 \\
(0.044)^{* * *}\end{array}$ & $\begin{array}{c}0.161 \\
(0.044)^{* * * *}\end{array}$ \\
\hline TE & $\begin{array}{r}-0.040 \\
(0.03)\end{array}$ & $\begin{array}{l}-0.088 \\
(0.038)^{* *}\end{array}$ & $\begin{array}{r}0.012 \\
(0.035)\end{array}$ & $\begin{array}{c}0.064 \\
(0.033)^{*}\end{array}$ & $\begin{array}{r}0.058 \\
(0.084)\end{array}$ & $\begin{array}{r}0.053 \\
(0.109)\end{array}$ & $\begin{array}{c}0.176 \\
(0.095)^{*}\end{array}$ & $\begin{array}{c}0.246 \\
(0.102)^{* *}\end{array}$ \\
\hline LFundage & $\begin{array}{l}-0.032 \\
(0.001)^{* * * *}\end{array}$ & $\begin{array}{l}-0.013 \\
(0.002)^{* * * *}\end{array}$ & $\begin{array}{l}-0.015 \\
(0.002)^{* * * *}\end{array}$ & $\begin{array}{l}-0.014 \\
(0.002)^{* * *}\end{array}$ & $\begin{array}{c}-0.01 \\
(0.004)^{* * * *}\end{array}$ & $\begin{array}{l}-0.012 \\
(0.004)^{* * *}\end{array}$ & $\begin{array}{l}-0.010 \\
(0.004)^{* *}\end{array}$ & $\begin{array}{l}-0.011 \\
(0.004)^{* * * *}\end{array}$ \\
\hline LAssetsize & $\begin{array}{l}-0.007 \\
(0.001)^{* * * *}\end{array}$ & $\begin{array}{l}-0.006 \\
(0.000)^{* * * *}\end{array}$ & $\begin{array}{l}-0.006 \\
(0.000)^{* * *}\end{array}$ & $\begin{array}{l}-0.006 \\
(0.000)^{* * *}\end{array}$ & $\begin{array}{l}-0.004 \\
(0.002)^{*}\end{array}$ & $\begin{array}{l}-0.006 \\
(0.003)^{*}\end{array}$ & $\begin{array}{l}-0.006 \\
(0.003)^{* *}\end{array}$ & $\begin{array}{l}-0.006 \\
(0.004)^{*}\end{array}$ \\
\hline Yeardummy & $\begin{array}{c}0.002 \\
(0.001)^{* * * *}\end{array}$ & $\begin{array}{c}0.003 \\
(0.000)^{* * * *}\end{array}$ & $\begin{array}{c}0.004 \\
(0.000)^{* * *}\end{array}$ & $\begin{array}{c}0.004 \\
(0.000)^{* * *}\end{array}$ & $\begin{array}{l}-0.001 \\
(0.001)^{* * *}\end{array}$ & $\begin{array}{r}0.001 \\
(0.001)\end{array}$ & $\begin{array}{r}0.001 \\
(0.001)\end{array}$ & $\begin{array}{r}0.001 \\
(0.001)\end{array}$ \\
\hline High-Mid & $\begin{array}{c}0.217 \\
(0.022)^{* * * *}\end{array}$ & $\begin{array}{c}0.180 \\
(0.027)^{* * *}\end{array}$ & $\begin{array}{c}0.059 \\
(0.028)^{* *}\end{array}$ & $\begin{array}{r}0.015 \\
(0.028)\end{array}$ & $\begin{array}{r}0.061 \\
(0.046)\end{array}$ & $\begin{array}{l}-0.107 \\
(0.049)^{* *}\end{array}$ & $\begin{array}{r}0.017 \\
(0.036)\end{array}$ & $\begin{array}{r}0.033 \\
(0.041)\end{array}$ \\
\hline Mid-Low & $\begin{array}{l}-0.001 \\
(0.018)\end{array}$ & $\begin{array}{r}0.031 \\
(0.023)\end{array}$ & $\begin{array}{l}-0.025 \\
(0.022)\end{array}$ & $\begin{array}{l}-0.007 \\
(0.022)\end{array}$ & $\begin{array}{l}-0.063 \\
(0.036)^{*}\end{array}$ & $\begin{array}{l}-0.036 \\
(0.061)\end{array}$ & $\begin{array}{l}-0.123 \\
(0.039)^{* * *}\end{array}$ & $\begin{array}{l}-0.116 \\
(0.035)^{* * * *}\end{array}$ \\
\hline High-Low & $\begin{array}{c}0.216 \\
(0.025)^{* * * *}\end{array}$ & $\begin{array}{c}0.211 \\
(0.031)^{* * * *}\end{array}$ & $\begin{array}{r}0.034 \\
(0.031)\end{array}$ & $\begin{array}{r}0.008 \\
(0.030)\end{array}$ & $\begin{array}{l}-0.002 \\
(0.054)\end{array}$ & $\begin{array}{l}-0.143 \\
(0.070)^{* *}\end{array}$ & $\begin{array}{l}-0.106 \\
(0.044)^{* *}\end{array}$ & $\begin{array}{l}-0.084 \\
(0.044)^{*}\end{array}$ \\
\hline $\mathrm{R}^{2}$ & 0.057 & 0.066 & 0.064 & 0.063 & 0.032 & 0.061 & 0.065 & 0.064 \\
\hline Sample & 190,331 & 119,772 & 119,772 & 119,772 & 6,739 & 3,787 & 3,787 & 3,787 \\
\hline
\end{tabular}


한국증권학회지 제48권 5호 (2019)

반면에 연기금 위탁펀드의 경우에는 자료에 따라서 상당한 결과의 차이를 볼 수 있다. 월별 자료를 사용하였을 경우 Low와 Mid 그룹에서 위험조정성과지표로 측정한 전기 성과와 현금 흐름과 통계적으로 유의한 양의 상관관계가 있으나, 6 개월과 연 자료에서는 이와 같은 관계를

\section{〈표 7〉6개월 자료를 사용한 과거 성과와 현금흐름의 관계 분석}

Flow $_{\mathrm{i}, \mathrm{t}}=\mathrm{a}+\mathrm{b}_{1} \mathrm{Low}_{\mathrm{i}, \mathrm{t}-1}+\mathrm{b}_{2} \mathrm{Mid}_{\mathrm{i}, \mathrm{t}-1}+\mathrm{b}_{3} \mathrm{High}_{\mathrm{i}, \mathrm{t}-\mathrm{1}}+\mathrm{b}_{4} \mathrm{LFamilysize}_{\mathrm{i}, \mathrm{t}}+\mathrm{b}_{5}$ Annualvol $_{\mathrm{i}, \mathrm{t}}+\mathrm{b}_{6} \mathrm{ICI}_{\mathrm{i}, \mathrm{t}}+\mathrm{b}_{7} \mathrm{Fl}_{\mathrm{i}} \mathrm{i}, \mathrm{t}-1+\mathrm{b}_{8} \mathrm{TE}_{\mathrm{i}, \mathrm{t}}$ $+\mathrm{b}_{9}$ LFundage $_{\mathrm{i}, \mathrm{t}}+\mathrm{b}_{10} \mathrm{LAssetsize}_{\mathrm{i}, \mathrm{t}}+\mathrm{b}_{11}$ Yeardummy $_{\mathrm{i}, \mathrm{t}}+\mathrm{e}_{\mathrm{i}, \mathrm{t}}$ (단계적 회귀분석 모형)

Flow $_{i, t}$ 는 펀드 $i$ 의 $t$ 시점에서의 현금흐름이고, Rank $_{\mathrm{i},-1}$ 는 펀드 $\mathrm{i}$ 의 $\mathrm{t}-1$ 의 수익률을 기준으로 펀드 유형별로 0 부터 1 까지 부여된 순위이다. Low $_{\mathrm{i}, \mathrm{t}-1}$ 는 Ranki,t-1 과 0.2 중 최소값이고, $\mathrm{Mid}_{\mathrm{i}, \mathrm{t}-1}$ 는 Rank $\mathrm{R}_{\mathrm{i}, \mathrm{t}-1}-\mathrm{Low}_{\mathrm{i}, \mathrm{t}-1}$ 과 0.6 중 최소값이며, $\mathrm{High}_{\mathrm{i}, \mathrm{t}-1}$ 는

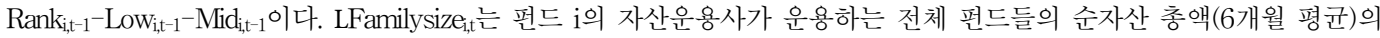
로그 값이며, Annualvoli,t는 펀드 $\mathrm{i}$ 의 과거 12 개월간 주간수익률의 표준편차(6개월 평균), $\mathrm{ICI}_{\mathrm{i}, \mathrm{t}}$ 는 펀드 $\mathrm{i}$ 의 $\mathrm{t}$ 시점에서의 산업집중도(6개월 평균)이고, $\mathrm{Flow}_{\mathrm{i}, \mathrm{t}-1}$ 는 펀드 $\mathrm{i}$ 의 전기 현금흐름, $\mathrm{TE}_{\mathrm{i}, \mathrm{t}}$ 는 펀드 $\mathrm{i}$ 의 $\mathrm{t}$ 시점에서의 트레킹에러(6개월

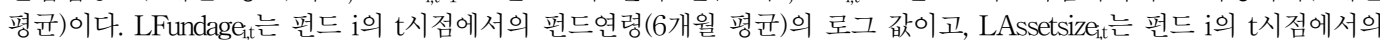
순자산(6개월 평균)의 로그 값이며, Yeardummyi,t는 연도 더미다. 괄호 안은 cluster robust 표준 오차이며 유의확률 $1 \%, 5 \%, 10 \%$ 수준에 대하여 각각 ${ }^{* * *},{ }^{* *},{ }^{*}$ 로 표시하였다.

\begin{tabular}{|c|c|c|c|c|c|c|c|c|}
\hline \multirow[b]{2}{*}{ 설명변수 } & \multicolumn{4}{|c|}{ 공모 주식펀드 } & \multicolumn{4}{|c|}{ 연기금 위탁주식펀드 } \\
\hline & $\begin{array}{l}\mathrm{BM} \\
\text { 초과 }\end{array}$ & $\begin{array}{l}\text { Jensen } \\
\text { 알파 }\end{array}$ & $\begin{array}{l}\mathrm{F}-\mathrm{F} \\
\text { 알파 }\end{array}$ & $\begin{array}{l}\text { Carhart } \\
\text { 알파 }\end{array}$ & $\begin{array}{l}\mathrm{BM} \\
\text { 초과 }\end{array}$ & $\begin{array}{l}\text { Jensen } \\
\text { 알파 }\end{array}$ & $\begin{array}{l}\mathrm{F}-\mathrm{F} \\
\text { 알파 }\end{array}$ & $\begin{array}{l}\text { Carhart } \\
\text { 알파 }\end{array}$ \\
\hline Low & $\begin{array}{r}0.256 \\
(0.267)\end{array}$ & $\begin{array}{c}0.583 \\
(0.217)^{* * *}\end{array}$ & $\begin{array}{r}0.355 \\
(0.262)\end{array}$ & $\begin{array}{r}0.200 \\
(0.265)\end{array}$ & $\begin{array}{c}0.961 \\
(0.266)^{* * *}\end{array}$ & $\begin{array}{r}0.798 \\
(0.479)\end{array}$ & $\begin{array}{c}0.894 \\
(0.400)^{* * *}\end{array}$ & $\begin{array}{c}0.937 \\
(0.344)^{* * * *}\end{array}$ \\
\hline Mid & $\begin{array}{r}0.030 \\
(0.054)\end{array}$ & $\begin{array}{c}0.502 \\
(0.072)^{* * * *}\end{array}$ & $\begin{array}{c}0.515 \\
(0.071)^{* * *}\end{array}$ & $\begin{array}{c}0.522 \\
(0.070)^{* * *}\end{array}$ & $\begin{array}{c}0.183 \\
(0.092)^{* *}\end{array}$ & $\begin{array}{r}0.113 \\
(0.086)\end{array}$ & $\begin{array}{r}0.036 \\
(0.083)\end{array}$ & $\begin{array}{r}0.007 \\
(0.089)\end{array}$ \\
\hline High & $\begin{array}{c}2.285 \\
(0.358)^{* * * *}\end{array}$ & $\begin{array}{c}1.802 \\
(0.438)^{* * *}\end{array}$ & $\begin{array}{c}1.027 \\
(0.456)^{* *}\end{array}$ & $\begin{array}{c}0.796 \\
(0.404)^{* *}\end{array}$ & $\begin{array}{r}0.105 \\
(0.479)\end{array}$ & $\begin{array}{r}0.418 \\
(0.369)\end{array}$ & $\begin{array}{c}0.771 \\
(0.378)^{* *}\end{array}$ & $\begin{array}{c}0.977 \\
(0.386)^{* *}\end{array}$ \\
\hline LFamilysize & $\begin{array}{c}0.058 \\
(0.012)^{* * * *}\end{array}$ & $\begin{array}{l}-0.002 \\
(0.012)\end{array}$ & $\begin{array}{r}0.001 \\
(0.012)\end{array}$ & $\begin{array}{r}0.004 \\
(0.012)\end{array}$ & $\begin{array}{r}0.034 \\
(0.023)\end{array}$ & $\begin{array}{r}0.002 \\
(0.032)\end{array}$ & $\begin{array}{r}0.005 \\
(0.032)\end{array}$ & $\begin{array}{r}0.004 \\
(0.032)\end{array}$ \\
\hline Annualvol & $\begin{array}{r}0.233 \\
(0.145)\end{array}$ & $\begin{array}{c}0.558 \\
(0.155)^{* * * *}\end{array}$ & $\begin{array}{c}0.599 \\
(0.156)^{* * *}\end{array}$ & $\begin{array}{c}0.633 \\
(0.156)^{* * *}\end{array}$ & $\begin{array}{l}-0.169 \\
(0.393)\end{array}$ & $\begin{array}{l}-0.989 \\
(0.235)^{* * *}\end{array}$ & $\begin{array}{l}-0.961 \\
(0.232)^{* * *}\end{array}$ & $\begin{array}{l}-0.951 \\
(0.232)^{* * * *}\end{array}$ \\
\hline ICI & $\begin{array}{l}-0.039 \\
(0.067)\end{array}$ & $\begin{array}{r}0.030 \\
(0.075)\end{array}$ & $\begin{array}{l}-0.039 \\
(0.081)\end{array}$ & $\begin{array}{l}-0.061 \\
(0.080)\end{array}$ & $\begin{array}{l}-0.808 \\
(0.144)^{* * *}\end{array}$ & $\begin{array}{l}-2.646 \\
(0.766)^{* * *}\end{array}$ & $\begin{array}{l}-1.699 \\
(0.713)^{* *}\end{array}$ & $\begin{array}{l}-1.164 \\
(0.741)\end{array}$ \\
\hline Flow $(\mathrm{t}-1)$ & $\begin{array}{c}0.062 \\
(0.011)^{* * * *}\end{array}$ & $\begin{array}{c}0.108 \\
(0.014)^{* * *}\end{array}$ & $\begin{array}{c}0.114 \\
(0.014)^{* * *}\end{array}$ & $\begin{array}{c}0.117 \\
(0.014)^{* * *}\end{array}$ & $\begin{array}{c}0.109 \\
(0.046)^{* *}\end{array}$ & $\begin{array}{c}0.295 \\
(0.088)^{* * *}\end{array}$ & $\begin{array}{c}0.294 \\
(0.096)^{* * *}\end{array}$ & $\begin{array}{c}0.305 \\
(0.087)^{* * * *}\end{array}$ \\
\hline $\mathrm{TE}$ & $\begin{array}{r}0.399 \\
(0.436)\end{array}$ & $\begin{array}{l}-0.074 \\
(0.378)\end{array}$ & $\begin{array}{r}0.603 \\
(0.386)\end{array}$ & $\begin{array}{c}0.980 \\
(0.392)^{* *}\end{array}$ & $\begin{array}{r}0.157 \\
(0.848)\end{array}$ & $\begin{array}{r}0.096 \\
(1.392)\end{array}$ & $\begin{array}{r}0.587 \\
(1.194)\end{array}$ & $\begin{array}{r}0.560 \\
(1.209)\end{array}$ \\
\hline LFundage & $\begin{array}{l}-0.263 \\
(0.025)^{* * *}\end{array}$ & $\begin{array}{l}-0.008 \\
(0.033)\end{array}$ & $\begin{array}{l}-0.023 \\
(0.033)\end{array}$ & $\begin{array}{l}-0.016 \\
(0.033)\end{array}$ & $\begin{array}{l}-0.064 \\
(0.040)\end{array}$ & $\begin{array}{l}-0.068 \\
(0.032)^{* * *}\end{array}$ & $\begin{array}{l}-0.045 \\
(0.027)\end{array}$ & $\begin{array}{l}-0.050 \\
(0.025)^{*}\end{array}$ \\
\hline LAssetsize & $\begin{array}{l}-0.099 \\
(0.007)^{* * * *}\end{array}$ & $\begin{array}{l}-0.087 \\
(0.007)^{* * *}\end{array}$ & $\begin{array}{l}-0.084 \\
(0.007)^{* * *}\end{array}$ & $\begin{array}{l}-0.083 \\
(0.007)^{* * *}\end{array}$ & $\begin{array}{l}-0.106 \\
(0.033)^{* * *}\end{array}$ & $\begin{array}{l}-0.113 \\
(0.044)^{* *}\end{array}$ & $\begin{array}{l}-0.112 \\
(0.045)^{* *}\end{array}$ & $\begin{array}{l}-0.114 \\
(0.046)^{* *}\end{array}$ \\
\hline Yeardummy & $\begin{array}{c}0.010 \\
(0.004)^{* *}\end{array}$ & $\begin{array}{c}0.037 \\
(0.005)^{* * * *}\end{array}$ & $\begin{array}{c}0.038 \\
(0.005)^{* * *}\end{array}$ & $\begin{array}{c}0.040 \\
(0.005)^{* * *}\end{array}$ & $\begin{array}{r}0.006 \\
(0.008)\end{array}$ & $\begin{array}{r}0.009 \\
(0.014)\end{array}$ & $\begin{array}{r}0.007 \\
(0.014)\end{array}$ & $\begin{array}{r}0.009 \\
(0.015)\end{array}$ \\
\hline High-Mid & $\begin{array}{c}2.255 \\
(0.382)^{* * *}\end{array}$ & $\begin{array}{c}1.300 \\
(0.469)^{* * *}\end{array}$ & $\begin{array}{r}0.512 \\
(0.490)\end{array}$ & $\begin{array}{r}0.274 \\
(0.436)\end{array}$ & $\begin{array}{l}-0.078 \\
(0.527)\end{array}$ & $\begin{array}{r}0.304 \\
(0.383)\end{array}$ & $\begin{array}{c}0.735 \\
(0.434)^{*}\end{array}$ & $\begin{array}{c}0.969 \\
(0.445)^{* *}\end{array}$ \\
\hline Mid-Low & $\begin{array}{l}-0.227 \\
(0.297)\end{array}$ & $\begin{array}{l}-0.081 \\
(0.256)\end{array}$ & $\begin{array}{r}0.161 \\
(0.300)\end{array}$ & $\begin{array}{r}0.321 \\
(0.304)\end{array}$ & $\begin{array}{l}-0.778 \\
(0.329)^{* *}\end{array}$ & $\begin{array}{l}-0.684 \\
(0.533)\end{array}$ & $\begin{array}{l}-0.858 \\
(0.445)^{*}\end{array}$ & $\begin{array}{l}-0.930 \\
(0.398)^{* *}\end{array}$ \\
\hline High-Low & $\begin{array}{c}2.028 \\
(0.441)^{* * * *}\end{array}$ & $\begin{array}{c}1.219 \\
(0.469)^{* * *}\end{array}$ & $\begin{array}{r}0.673 \\
(0.494)\end{array}$ & $\begin{array}{r}0.596 \\
(0.447)\end{array}$ & $\begin{array}{l}-0.856 \\
(0.531)\end{array}$ & $\begin{array}{l}-0.380 \\
(0.696)\end{array}$ & $\begin{array}{l}-0.123 \\
(0.429)\end{array}$ & $\begin{array}{r}0.039 \\
(0.349)\end{array}$ \\
\hline $\mathrm{R}^{2}$ & 0.060 & 0.059 & 0.055 & 0.053 & 0.097 & 0.135 & 0.141 & 0.142 \\
\hline Sample & 26,647 & 15,500 & 15,500 & 15,500 & 931 & 499 & 499 & 499 \\
\hline
\end{tabular}


Comparative Analysis on the Flow-Performance Relationship between Public Equity and Fiduciary Pension Funds

볼 수 없으며, 특별히 연 자료를 사용하였을 경우 Jensen 알파의 경우를 제외하고는 전기 성과와 현금흐름과의 일관성 있는 상관관계를 확인할 수 없고 공모펀드에서 관찰되었던 전기 성과와 현금흐름의 볼록성 관계를 관찰할 수 없었다. 이 결과에 대해 좀 더 명확한 검증을 위한 High,

〈표 8〉연 자료를 사용한 과거 성과와 현금흐름의 관계 분석

Flow $_{\mathrm{i}, \mathrm{t}}=\mathrm{a}^{+} \mathrm{b}_{1} \mathrm{Low}_{\mathrm{i}, \mathrm{t}-1}+\mathrm{b}_{2} \mathrm{Mid}_{\mathrm{i}, \mathrm{t}-1}+\mathrm{b}_{3} \mathrm{High}_{\mathrm{i}, \mathrm{-}-1}+\mathrm{b}_{4} \mathrm{LFamilysize}_{\mathrm{i}, \mathrm{t}}+\mathrm{b}_{5}$ Annualvol $_{\mathrm{i}, \mathrm{t}}+\mathrm{b}_{6} \mathrm{ICl}_{\mathrm{i}, \mathrm{t}}+\mathrm{b}_{7} \mathrm{Flow}_{\mathrm{i}, \mathrm{t}-1}+\mathrm{b}_{8} \mathrm{TE}_{\mathrm{i}, \mathrm{t}}$ $+\mathrm{b}_{9}$ LFundage $_{\mathrm{i}, \mathrm{t}}+\mathrm{b}_{10} \mathrm{~L}$ Assetsize $\mathrm{e}_{\mathrm{i}, \mathrm{t}}+\mathrm{b}_{11}$ Yeardummy $_{\mathrm{i}, \mathrm{t}}+\mathrm{e}_{\mathrm{i}, \mathrm{t}}$ (단계적 회귀분석 모형)

Flow $_{\mathrm{i}, \mathrm{L}}$ 는 펀드 $\mathrm{i}$ 의 $\mathrm{t}$ 시점에서의 현금흐름이고, $\mathrm{Rank}_{\mathrm{i}, \mathrm{t}-1}$ 는 펀드 $\mathrm{i}$ 의 $\mathrm{t}-1$ 년의 수익률을 기준으로 펀드 유형별로 0 부터

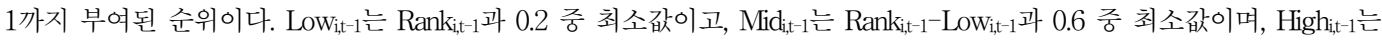
$\mathrm{Rank}_{\mathrm{i}, \mathrm{t}-1}-\mathrm{Low}_{\mathrm{i}, \mathrm{t}-1}-\mathrm{Mid}_{\mathrm{i}, t-1}$ 이다. LFamilysize $\mathrm{i}, \mathrm{t}$ 는 펀드 $\mathrm{i}$ 의 자산운용사가 운용하는 전체 펀드들의 순자산 총액(연평균)의 로그 값이며, Annualvoli, 산업집중도(연평균)이고, $\mathrm{Flow}_{\mathrm{i}, \mathrm{t}-1}$ 는 펀드 $\mathrm{i}$ 의 전년 현금흐름, $\mathrm{TE}_{\mathrm{i}, \mathrm{t}}$ 는 펀드 $\mathrm{i}$ 의 $\mathrm{t}$ 시점에서의 트레킹에러(연평균)이다. LFundage $e_{i,}$ 는 펀드 $i$ 의 $t$ 시점에서의 펀드연령(연평균)의 로그 값이고, LAssetsize $e_{i, t}$ 는 펀드 $i$ 의 $t$ 시점에서의 순자산 (연평균)의 로그 값이며, Yeardummy $\mathrm{y}_{\mathrm{i}, \mathrm{L}}$ 는 연도 더미다. 괄호 안은 cluster robust 표준 오차이며 유의확률 $1 \%, 5 \%$, $10 \%$ 수준에 대하여 각각 ${ }^{* * *},{ }^{* *},{ }^{*}$ 로 표시하였다.

\begin{tabular}{|c|c|c|c|c|c|c|c|c|}
\hline \multirow[b]{2}{*}{ 설명변수 } & \multicolumn{4}{|c|}{ 공모 주식펀드 } & \multicolumn{4}{|c|}{ 연기금 위탁주식펀드 } \\
\hline & $\begin{array}{l}\mathrm{BM} \\
\text { 초과 }\end{array}$ & $\begin{array}{l}\text { Jensen } \\
\text { 알파 }\end{array}$ & $\begin{array}{l}\mathrm{F}-\mathrm{F} \\
\text { 알파 }\end{array}$ & $\begin{array}{l}\text { Carhart } \\
\text { 알파 }\end{array}$ & $\begin{array}{l}\mathrm{BM} \\
\text { 초과 }\end{array}$ & $\begin{array}{l}\text { Jensen } \\
\text { 알파 }\end{array}$ & $\begin{array}{l}\mathrm{F}-\mathrm{F} \\
\text { 알파 }\end{array}$ & $\begin{array}{l}\text { Carhart } \\
\text { 알파 }\end{array}$ \\
\hline \multirow[t]{2}{*}{ Low } & 0.538 & 1.559 & 0.640 & 0.729 & 1.238 & 3.112 & -0.524 & -0.040 \\
\hline & $(0.632)$ & $(0.725)^{* *}$ & $(0.835)$ & $(0.926)$ & $(0.785)$ & $(1.502)^{* *}$ & (1.890) & (1.268) \\
\hline \multirow[t]{2}{*}{ Mid } & 0.419 & 1.188 & 0.793 & 0.743 & 0.380 & 0.127 & 0.162 & 0.367 \\
\hline & $(0.150)^{* * * *}$ & $(0.213)^{* * *}$ & $(0.229)^{* * *}$ & $(0.215)^{* * *}$ & $(0.284)$ & $(0.252)$ & $(0.265)$ & $(0.263)$ \\
\hline \multirow[t]{2}{*}{ High } & 5.904 & 5.493 & 5.275 & 4.659 & 0.939 & 1.150 & 0.498 & 0.749 \\
\hline & $(1.128)^{* * *}$ & $(1.409)^{* * *}$ & $(1.365)^{* * *}$ & $(1.220)^{* * *}$ & $(1.007)$ & (1.189) & $(0.873)$ & $(0.825)$ \\
\hline \multirow[t]{2}{*}{ LFamilysize } & 0.121 & -0.006 & 0.005 & 0.018 & 0.032 & -0.003 & 0.039 & 0.028 \\
\hline & $(0.032)^{* * *}$ & $(0.039)$ & $(0.040)$ & $(0.040)$ & $(0.058)$ & $(0.113)^{* * *}$ & $(0.117)$ & $(0.117)$ \\
\hline \multirow[t]{2}{*}{ Annualvol } & 1.307 & 1.362 & 1.226 & 1.204 & -1.184 & -2.016 & -1.912 & -2.096 \\
\hline & $(0.445)^{* * *}$ & $(0.609)^{* *}$ & $(0.622)^{* *}$ & $(0.632)^{*}$ & $(0.449)^{* *}$ & $(0.730)^{* * *}$ & $(0.701)^{* * *}$ & $(0.674)^{* * *}$ \\
\hline \multirow[t]{2}{*}{ ICI } & -0.094 & -0.020 & -0.288 & -0.308 & -2.825 & -9.287 & -5.223 & -4.998 \\
\hline & (0.170) & (0.213) & $(0.232)$ & (0.228) & $(1.165)^{* *}$ & $(4.752)^{*}$ & (3.491) & (3.681) \\
\hline \multirow[t]{2}{*}{ Flow $(t-1)$} & 0.050 & 0.060 & 0.071 & 0.077 & 0.056 & 0.227 & 0.282 & 0.249 \\
\hline & $(0.017)^{* * *}$ & $(0.026)^{* *}$ & $(0.027)^{* * *}$ & $(0.027)^{* * *}$ & $(0.031)^{*}$ & $(0.146)$ & $(0.165)^{*}$ & (0.153) \\
\hline \multirow[t]{2}{*}{ TE } & 1.403 & 1.838 & 2.452 & 3.097 & 1.802 & 0.211 & 0.141 & 1.460 \\
\hline & (1.044) & (1.365) & $(1.327)^{*}$ & $(1.342)^{* *}$ & (2.412) & (3.989) & (3.621) & (3.427) \\
\hline \multirow[t]{2}{*}{ LFundage } & -0.078 & 0.021 & -0.055 & -0.056 & -0.151 & -0.097 & -0.168 & -0.150 \\
\hline & $(0.076)$ & $(0.146)$ & (0.145) & $(0.144)$ & $(0.111)$ & (0.104) & $(0.130)$ & (0.105) \\
\hline \multirow[t]{2}{*}{ LAssetsize } & -0.232 & -0.253 & -0.241 & -0.240 & -0.289 & -0.455 & -0.417 & -0.423 \\
\hline & $(0.019)^{* * * *}$ & $(0.025)^{* * *}$ & $(0.024)^{* * *}$ & $(0.025)^{* * *}$ & $(0.103)^{* * * *}$ & $(0.186)^{* *}$ & $(0.176)^{* *}$ & $(0.183)^{* *}$ \\
\hline \multirow[t]{2}{*}{ Yeardummy } & 0.035 & 0.113 & 0.088 & 0.093 & 0.042 & 0.063 & 0.034 & 0.049 \\
\hline & $(0.013)^{* * * *}$ & $(0.021)^{* * * *}$ & $(0.021)^{* * * *}$ & $(0.020)^{* * * *}$ & $(0.025)$ & $(0.052)$ & $(0.043)$ & $(0.050)$ \\
\hline \multirow[t]{2}{*}{ High-Mid } & 5.485 & 4.304 & 4.482 & 3.917 & 0.560 & 1.023 & 0.336 & 0.382 \\
\hline & $(1.201)^{* * *}$ & $(1.497)^{* * * *}$ & $(1.468)^{* * * *}$ & $(1.294)^{* * *}$ & (1.198) & (1.323) & (1.036) & (0.932) \\
\hline \multirow[t]{2}{*}{ Mid-Low } & -0.119 & -0.371 & 0.153 & 0.014 & -0.859 & -2.985 & 0.686 & 0.407 \\
\hline & $(0.717)$ & (0.825) & (0.963) & (1.057) & (0.993) & $(1.632)^{*}$ & (2.017) & (1.320) \\
\hline \multirow[t]{2}{*}{ High-Low } & 5.367 & 3.934 & 4.635 & 3.931 & -0.299 & -1.962 & 1.022 & 0.789 \\
\hline & $(1.273)^{* * * *}$ & $(1.526)^{* *}$ & $(1.501)^{* * * *}$ & $(1.443)^{* * * *}$ & (1.226) & $(1.215$ & (1.705) & (1.039) \\
\hline $\mathrm{R}^{2}$ & 0.071 & 0.086 & 0.077 & 0.073 & 0.187 & 0.239 & 0.202 & 0.211 \\
\hline Sample & 10,117 & 6,299 & 6,299 & 6,299 & 330 & 195 & 195 & 195 \\
\hline
\end{tabular}


한국증권학회지 제 48 권 5 호 (2019)

$\mathrm{Mid}, \mathrm{Low}$ 의 계수간의 차이 검증에서도 월별 자료를 사용했을 경우 위험조정성과지표의 경우 High 그룹과 Low 그룹의 차이가 통계적으로 유의한 음의 차이를 보이고 있는 것 외에는 전반적으로 High, Mid, Low의 계수간의 차이가 없는 것으로 나타나 미국의 연 자료를 사용하여 공모펀드와 연기금 위탁펀드의 전기 성과와 현금흐름의 관계를 분석하였던 Del Guercio and $T \mathrm{Tac}(2002)$ 의 결과와 비슷한 결과를 보이고 있다.4)

<그림 1>은 연 자료를 사용하여 공모펀드와 연기금 위탁펀드를 각각 네 가지 과거 성과지표 (BM 초과수익률, Jensen 알파, Fama-French 알파, Carhart 알파)를 기준으로 20개의 성과그룹 으로 나누어 각 성과그룹의 평균 현금흐름을 표시한 그림이다. 전반적으로 공모펀드의 경우에는 하위와 중위 성과그룹에 대해 현금흐름의 변화가 크지 않는 반면 상위 성과그룹에 대해서는 현금흐름이 급격히 증가하는 볼록성의 관계를 나타내고 있다. 그러나 연기금 위탁펀드의 경우에는 과거 성과와 현금흐름 사이에 공모펀드에서 나타나는 볼록성의 관계가 나타나지 않는다. 이는 $<$ 표 8>의 분석 결과와 동일하다.

〈그림 1〉연 자료를 사용한 과거 성과와 현금흐름의 관계 이 그림은 연 자료를 사용하여 공모펀드와 연기금 위탁펀드를 각각 네 가지 과거 성과지표(BM 초과수익률, Jensen 알파, Fama-French 알파, Carhart 알파)를 기준으로 20개의 성과그룹으로 나누어 각 성과그룹의 평균 현금흐름을 표시한 그림이다.
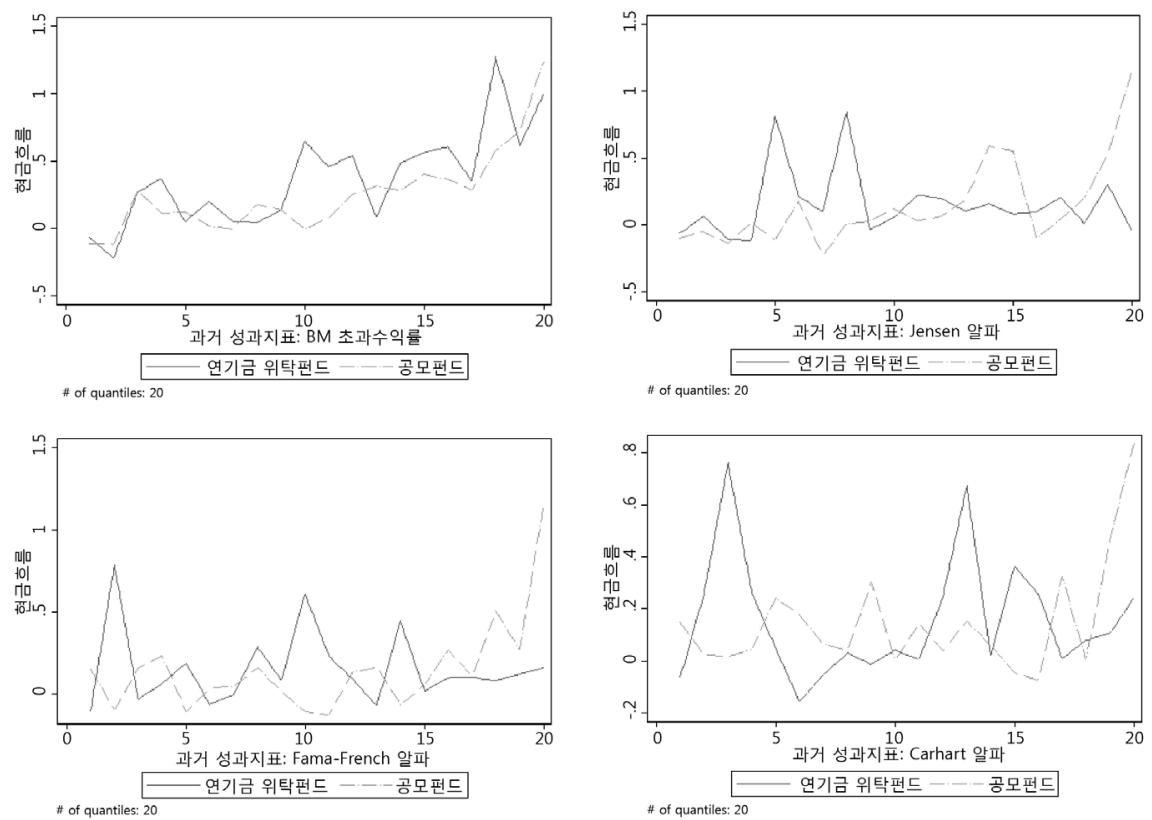

4) OLS 회귀분석은 정규 분포와 등분산성을 가정하고 있는데 Paek and $\mathrm{Ko}(2016)$ 는 펀드의 과거 성과와 현금흐름 관계 분석에 있어 이와 같은 가정을 만족하지 않는다고 하여 Koenker and Basset(1978)의 분위수 회귀분석(quantile regression)을 제안하였다. 본 연구는 강건성 검증을 위해 분위수 회귀분석을 추가로 시행하였고 위에서 보고한 결과와 비슷한 결과를 얻었다. 


\section{4 공모펀드와 연기금 위탁펀드의 성과와 현금흐름 관계 분석 결과에 대한 설명}

지금까지 제시한 공모펀드와 연기금 위탁펀드의 성과와 현금흐름 관계에 대한 실증 분석 결과는 미국의 연 자료를 사용하여 공모펀드와 연기금 위탁펀드의 전기 성과와 현금흐름의 관계를 분석하였던 Del Guercio and Tkac(2002)의 결과와 비슷하다고 하였다. 이와 같은 결과에 대해서 기존의 연구에서 제시되었던 설명을 먼저 알아보고자 한다. 기존 연구와의 비교를 위해 연 자료를 사용한 <표 8>의 결과를 사용하였다.

먼저 현금흐름과 펀드의 전기 현금흐름과의 관계는 공모펀드의 경우 통계적으로 유의한 양의 상관관계를 보이고 있으나 연기금 위탁펀드의 경우는 관계가 약하거나 없는 것으로 나타났다. 이에 대한 Del Guercio and Tkac(2002)의 설명은 공모펀드의 투자자들은 다수가 은퇴 후의 노후 자금을 저축하기 위해 펀드에 투자한 경우로서 장기간 투자를 하며 자동 이체 등을 통해 주기적으로 투자하며 단기적인 성과에 크게 영향을 받지 않는 반면 연기금펀드의 경우는 펀드의 성과에 따라 투자 추가나 환수를 함으로 공모펀드의 경우는 현금흐름과 펀드의 전기 현금흐름 사이에 높은 상관관계가 있으나 연기금펀드의 경우에는 그렇지 않다고 하였다.

또한 <표 8>에서 공모펀드와 연기금 위탁펀드에 공통적으로 나타나는 결과는 현금흐름과 펀드의 크기와는 통계적으로 유의한 음의 상관관계가 있다는 것이다. 그러나 Del Guercio and $\mathrm{Tkac}(2002)$ 의 결과는 <표 8>의 결과와 약간 다른데 그들의 연구에서는 현금흐름과 펀드의 크기 사이의 통계적으로 유의한 음의 결과는 연기금펀드의 경우에만 나타났다. 이에 대해 Del Guercio and Tkac(2002)는 연기금펀드의 투자자들은 공모펀드의 투자자들에 비해 펀드의 크기가 증가함에 따른 서비스 질의 하락이나 규모에 따른 수익률 감소 가능성을 훨씬 더 민감하게 받아들이기 때문에 이런 현상이 발생한다고 하였다. 본 연구의 <표 8>의 결과는 이 설명과는 다르게 공모펀드에서도 같은 결과를 나타내고 있으며 공모펀드나 연기금 위탁펀드 투자자들 사이에 차이가 없는 것으로 나타났다.

끝으로 본 연구의 핵심 주제인 펀드의 과거 성과와 현금흐름의 관계에 대해 알아보고자 한다. 본 연구의 <표 8>의 결과와 Del Guercio and Tkac(2002)의 결과는 비슷하게 나타났으며 공모펀드의 경우 펀드의 전기 성과와 현금흐름 간에는 볼록성의 관계가 있지만 연기금 위탁펀드의 경우에는 그와 같은 볼록성의 관계가 없는 것으로 나타났다. 공모펀드의 경우 과거 성과와 현금흐름의 볼록성 관계가 있다는 것은 전기의 성과가 좋은 펀드는 예상한 대로 더 많은 현금 유입이 있으나 전기의 성과가 좋지 않은 펀드는 저조한 성과에 따라 예상되는 현금 유출이 없다는 것을 의미한다. 반면에 연기금 위탁펀드에 대해서는 그와 같은 과거 성과와 현금흐름의 볼록성 관계가 관찰되지 않고 과거 성과에 따라 현금흐름이 예상하는 대로 발생하는 것이다.

이에 대해 Del Guercio and Tkac(2002)는 두 가지 가능성을 제시하고 있다. 첫 번째 가능성은 공모펀드와 연기금 위탁펀드 투자자들에 대해 과세대상 여부의 차이점 때문에 이와 같은 현상이 발생할 수 있다고 하였다. 즉 공모펀드의 투자자들은 자본 이득에 대해 과세 대상이지만 연기금펀드의 투자자들은 비과세이기 때문에 공모펀드의 투자자들은 성과가 저조한 펀드를 환매할 때 자본 이득이 있을 경우 그에 대한 세금을 내야하는 부담이 있지만 연기금 위탁펀드의 
한국증권학회지 제48권 5호 (2019)

투자자들은 그와 같은 부담이 없기 때문에 자유롭게 성과가 저조한 펀드를 환수할 수 있고 이에 따라 위의 차이가 발생할 수 있다고 하였다. 두 번째 가능성은 위에서 현금흐름과 펀드의 전기 현금흐름과의 관계에서 설명한 대로 공모펀드의 투자자들은 다수가 은퇴 후의 노후 자금을 저축하기 위해 펀드에 투자한 경우로서 장기간 투자를 하고 자동 이체 등을 통해 주기적으로 투자하며 단기적인 성과에 크게 영향을 받지 않는 반면 연기금 위탁펀드의 경우는 펀드의 성과에 따라 투자 추가나 환수를 함으로 공모펀드의 경우는 현금흐름과 펀드의 전기 현금흐름 사이에 높은 상관관계가 있으나 연기금 위탁펀드의 경우에는 그렇지 않기 때문에 위의 차이가 발생할 수 있다고 하였다. 이 두 가지 가능성 가운데 어떤 것이 더 큰 설명력을 갖는지에 대해 본 연구의 결과가 시사하는 바는 다음과 같다. 한국의 경우 주식형 펀드에 대해서는 매매차익으로 인한 자본이득에 대해서 소득세가 비과세되므로 공모펀드의 투자자들도 환매 시 자본이득에 대한 세금 납부에 대한 부담이 없으므로 공모펀드와 연기금 위탁펀드 투자자들에 대해 과세대상 여부의 차이점 때문에 이와 같은 현상이 발생할 수 있다고 한 첫 번째 가능성은 큰 설명력이 없다고 판단된다. 위의 결과에 대한 한 가지 정책적 시사점은 공모펀드와 관련하여 펀드의 과거 성과와 현금흐름의 볼록성 관계로 인하여 공모펀드의 운영자들은 좀 더 위험한 투자를 선호하는 대리인 문제가 발생할 가능성이 많이 있다는 점도 투자자들과 감독기관이 유념해야 할 점이라는 것이다.

Chen et al.(2010)에 따르면 유동성이 낮은 자산(illiquid assets)에 주로 투자한 주식형 펀드의 경우 현금흐름과 성과와의 관계에 있어 볼록성이 아닌 오목성이 나타난다고 보고하였다. 따라서 연기금 위탁펀드에서 볼록성이 나타나지 않은 또 다른 가능성은 연기금 위탁펀드의 운용행태가 공모펀드와는 달리 소형주 혹은 가치주 중심의 유동성이 낮은 자산에 투자한 것 때문일 수도 있다.5) 이에 대해 공모펀드와 연기금 위탁펀드의 운용행태에 차이가 있는 지를 살펴보기 위해 Fama-French 모형 및 Carhart 모형의 베타를 비교 분석하였다. 이를 위해 펀드 베타를 종속 변수로, 연기금 위탁펀드와 공모펀드를 더미변수(연기금 위탁펀드 1 , 공모펀드 0)로 하여 회귀분석을 하였다. 연 자료를 이용하여 추정에 사용된 펀드의 전체 표본 수는 8,846 개이고, 공모펀드의 표본 수는 8,584개, 연기금 위탁펀드의 표본 수는 262 개이다.

<표 9>에서 보는 바와 같이 첫째, 연기금 위탁펀드의 시장요인 베타가 공모펀드 시장요인 베타에 비해 0.02 0.03 정도 높은 것으로 나타났다. 이는 연기금 위탁펀드의 경우 위탁자금의 95\% 이상이 주식에 편입되어야 하며 펀드규모도 공모펀드보다 크기 때문에 시장요인 베타가 공모펀드의 시장요인 베타보다 높게 나타난 것으로 보인다. 둘째, 연기금 위탁펀드는 공모펀드에 비해 규모요인 베타는 0.05 0.06 정도 크고, 가치요인 베타와 모멘텀요인 베타는 차이가 없는 것으로 나타나, 공모펀드보다 소형주 투자에 더 편향된 것으로 보인다. 이와 같은 결과는 연기금 위탁펀드에서 볼록성이 나타나지 않은 이유가 연기금 위탁펀드의 운용행태가 공모펀드와는 달리 소형주 중심의 유동성이 낮은 자산에 투자한 것 때문일 수도 있다는 점을 시사할 수 있으나 연기금 위탁펀드가 소형주 위주로만 투자하는 것은 아니고 연기금 위탁펀드의 펀드규모가

5) 이 가능성을 제안해 주신 익명의 심사위원께 감사드린다. 
Comparative Analysis on the Flow-Performance Relationship between Public Equity and Fiduciary Pension Funds

공모펀드보다 훨씬 큰 이유로 이와 같은 결과가 나타날 수도 있기 때문에 연기금 위탁펀드에서 볼록성이 나타나지 않은 이유가 펀드의 운용행태의 차이점 때문일 가능성은 낮아 보인다.

〈표 9〉 공모펀드와 연기금 위탁펀드의 베타 비교

이 표는 펀드 베타를 종속변수로, 연기금 위탁펀드와 공모펀드를 더미변수(연기금 위탁펀드 1 , 공모펀드 $0)$ 로 하여 회귀분석을 한 결과이다. 괄호 안은 cluster robust 표준 오차로 계산한 t값이며, 연 자료를 이용하여 추정에 사용된 펀드의 전체 표본 수는 8,846 개이고, 공모펀드의 표본 수는 8,584 개, 연기금 위탁펀드의 표본 수는 262 개이다. 유의확률 $1 \%, 5 \%, 10 \%$ 수준에 대하여 각각 ${ }^{* * *},{ }^{* *},{ }^{*}$ 로 표시하였다.

\begin{tabular}{|c|c|c|}
\hline 모형 & 베타 요인 & 계수 \\
\hline \multirow{3}{*}{ Fama-French } & 시장요인 & $\begin{array}{c}0.0245^{* *} \\
(2.53)\end{array}$ \\
\hline & 규모요인 & $\begin{array}{c}0.0578^{* *} \\
(2.18)\end{array}$ \\
\hline & 가치요인 & $\begin{array}{r}0.0085 \\
(0.55)\end{array}$ \\
\hline \multirow{4}{*}{ Carhart } & 시장요인 & $\begin{array}{c}0.0273^{* * *} \\
(3.02)\end{array}$ \\
\hline & 규모요인 & $\begin{array}{c}0.0511^{*} \\
(1.95)\end{array}$ \\
\hline & 가치요인 & $\begin{array}{r}0.0146 \\
(1.02)\end{array}$ \\
\hline & 모멘텀요인 & $\begin{array}{r}0.0112 \\
(0.79)\end{array}$ \\
\hline
\end{tabular}

\section{4. 결론}

본 연구의 목적은 공모펀드에 관한 많은 기존 연구에서 보여준 펀드의 성과와 현금흐름 간에 볼록성 관계가 공모펀드와는 성격이 다른 국내 연기금 위탁펀드에서도 존재하는지를 검증해 보는 것이다. 공모펀드와 연기금 위탁펀드의 성과와 현금흐름과의 관계를 검증한 국외 연구로는 미국의 연 자료를 사용하여 공모펀드와 연기금 위탁펀드의 전기 성과와 현금흐름의 관계를 분석하였던 Del Guercio and Tkac(2002)의 연구가 있으나 국내 연구는 대부분 공모펀드에 대한 연구이고 연기금 위탁펀드에 대한 연구는 거의 없어 본 연구가 유일하다고 할 수 있다.

본 연구는 먼저 OLS 회귀분석을 통해 일반적인 과거 성과와 현금흐름과의 관계를 먼저 살펴보았는데 모든 자료에 대해 공모펀드와 연기금 위탁펀드에 공통적으로 나타나는 결과는 현금흐름과 전기의 성과와는 통계적으로 유의한 양의 상관관계가 있다는 것이고 이는 일반적으로 기존 연구들의 결과와 비슷한 결과이다.

그 다음으로 공모펀드와 연기금 위탁펀드의 성과와 현금흐름의 볼록성 관계의 존재 여부를 확인하기 위해 단계적 선형 회귀분석(piecewise regression) 모형을 추정하여 과거 성과와 현금흐름의 관계를 검증하였다. 모든 자료에서 성과지표 중 BM 초과수익률과 Jensen 알파에 대해서 High 그룹과 Mid 그룹의 차이와 High 그룹과 Low 그룹의 차이는 통계적으로 유의한 
한국증권학회지 제48권 5호 (2019)

양의 차이를 보이고 있는 반면 모든 자료에서 Mid 그룹과 Low 그룹의 차이는 없는 것으로 나타나 전기 성과와 현금흐름 간에는 볼록성의 관계가 있다는 공모펀드에 대한 기존 연구 결과와 같은 결과를 얻었다. 반면에 연기금 위탁펀드의 경우에는 High, Mid, Low의 계수간의 차이 검증에서도 월별과 6개월 자료를 사용했을 때 일부 위험조정성과지표들의 High 그룹과 Low 그룹의 차이가 통계적으로 유의한 음의 차이를 보이고 있는 것 외에는 전반적으로 High, Mid, Low의 계수간의 차이가 없어 미국의 연 자료를 사용하여 연기금펀드에 대해서 전기 성과와 현금흐름 간에는 볼록성의 관계가 없는 것을 보인 Del Guercio and Tkac(2002)의 결과와 비슷한 결과를 얻었다.

이와 같이 공모펀드와 연기금 위탁펀드에 대해 다른 결과가 나타난 것에 대한 설명은 두 가지로 요약할 수 있는데 첫 번째는 공모펀드와 연기금 위탁펀드 투자자들에 대해 과세대상 여부의 차이점 때문에 이와 같은 현상이 발생할 수 있다는 것이고, 두 번째는 공모펀드와 연기금 위탁펀드 투자자들의 특성의 차이점 때문에 이와 같은 현상이 발생할 수 있다는 것이다. 이에 대해 본 연구의 결과가 시사하는 바는 다음과 같다. 한국의 경우 미국과는 달리 주식형 펀드에 대해서는 매매차익으로 인한 자본이득에 대해서 소득세가 비과세되어 공모펀드의 투자자들도 환매 시 자본이득에 대한 세금 납부에 대한 부담이 없으므로 공모펀드와 연기금 위탁펀드 투자자들에 대해 과세대상 여부의 차이점 때문에 이와 같은 현상이 발생할 수 있다고 한 첫 번째 가능성은 큰 설명력이 없다고 여겨지며 두 번째 설명이 더 설득력이 있다고 판단된다. 위의 결과에 대한 한 가지 정책적 시사점은 공모펀드와 관련하여 펀드의 과거 성과와 현금흐름의 볼록성 관계로 인하여 공모펀드의 운영자들은 좀 더 위험한 투자를 선호하는 대리인 문제가 발생할 가능성이 많이 있다는 점도 투자자들과 감독기관이 유념해야 할 점이라는 것이다. 
Comparative Analysis on the Flow-Performance Relationship between Public Equity and Fiduciary Pension Funds

\section{References}

Carhart, M., 1997, On Persistence in Mutual Fund Returns, Journal of Finance, Vol. 52 (1), pp. 57-82.

Chen, Q., I. Goldstein, and W. Jiang, 2010, Payoff Complementarities and Financial Fragility: Evidence from Mutual Fund Outflows, Journal of Financial Economics, Vol. 97 (2), pp. 239-262.

Cheong, M., H. Sung, and H. Kim, 2015, A Comparative Analysis on the Performance, Style, and Performance Persistence between Public Equity Funds and Fiduciary Pension Funds, The Korean Journal of Financial Management, Vol. 32 (3), pp. 77-105.

Chevalier, J., and G. Ellison, 1997, Risk Taking by Mutual Funds as a Response to Incentives, Journal of Political Economy, Vol. 105 (6), pp. 1167-1200.

Del Guercio, D., and P. A. Tkac, 2002, The Determinants of the Flow of Funds of Managed Portpolios: Mutual Funds vs. Pension Funds, Journal of Financial and Quantitative Analysis, Vol. 37 (4), pp. 523-557.

Fama, E. F., and K. R. French, 1992, The Cross-Section of Expected Stock Returns, Journal of Finance, Vol. 47 (2), pp. 427-465.

Fama, E. F., and K. R. French, 1993, Common Risk Factors in the Returns on Stocks and Bonds, Journal of Financial Economics, Vol. 33 (1), pp. 3-56.

Ferreira, M. A., A. Keswani, A. F. Miguel, and S. B. Ramos, 2012, The Flow-performance Relationship Around the World, Journal of Banking and Finance, Vol. 36 (6), pp. 1759-1780.

Ha, Y., D. Kim, and K. Ko, 2014, Convex Flow-Performance Relationship of Equity Funds, Korean Journal of Financial Studies, Vol. 43 (5), pp. 911-936.

Jensen, M. C., 1968, The Performance of Mutual Funds in the Period 1945-1964, Journal of Finance, Vol. 23 (2), pp. 389-416.

Kacperczyk, M., C. Sialm, and L. Zheng, 2005, On the Industry Concentration of Actively Managed Equity Mutual Funds, Journal of Finance, Vol. 60 (4), pp. 1983-2011.

Koenker, R., and G. Bassett, 1978, Regression Quantiles, Econometrica, Vol. 46, pp. 33-50.

Paek, M., and K. Ko, 2016, New Insight on the Flow-Performance Relations, Journal of Money and Finance, Vol. 30 (3), pp. 49-76.

Sirri, E. R., and P. Tufano, 1998, Costly Search and Mutual Fund Flows, Journal of Finance, Vol. 53, pp. 1589-1621.

Spiegel, M., and H. Zhang, 2013, Mutual Fund Risk and Market Share Adjusted Fund Flows, Journal of Financial Economics, Vol. 108, pp. 506-528. 